\title{
Effect of Foliar Application with Salicylic Acid (Potasal), Mineral Phosphorus Levels and Inoculation Tomato Plant with Soluble Phosphorus Bacteria on Growth, Productivity and Reducing Disease Infect with Tomato Curly Top Virus (TCTV) El-Koumy, H. M. ${ }^{1}$; R. E. Knany ${ }^{2}$ and M. M. El-Sawy ${ }^{3}$ \\ ${ }^{1}$ Vegetable Research Department, Hort. Res. Inst. ARC, Egypt \\ ${ }^{2}$ Soils, Water and Environmental Research Institute, ARC, Egypt \\ ${ }^{3}$ Virus and Phitoplasma Department, Plant Disease Inst., ARC, Egypt
}

\section{ABSTRACT}

The objective of the present study is to investigate effect of phosphorus fertilizer levels and potassium salicylate spraying on tomato growth, yield, quality and curly top virus severity \% (TCTV) and incidence. Two field experiments were conducted in a private farm at El-Shamarka, Kafr El-Sheikh district, Kafr El-Sheikh governorate during 2014 and 2015 seasons. Split split plot design was used with four replicates. The main plots were assigned with three phosphorus levels 0,15 and $30 \mathrm{~kg} \mathrm{P}_{2} \mathrm{O}_{5} \mathrm{fed}^{-1}$. The sub plots were assigned with two potassium salicylate treatments of without potassium salicylate but sprayed by potassium $20 \% \mathrm{~K}_{2} \mathrm{O} 1$ liter in 200 liter water $\mathrm{fed}^{-1}$ and spraying with potassium salicylate $20 \% \mathrm{~K}_{2} \mathrm{O}, 12.5 \%$ salicylate at the rate $300 \mathrm{mg} \mathrm{L}^{-1}$ salicylic of the spraying solution. The sub sub plots were assigned with two biofertilizer treatments of without inoculation and inoculation with phosphate solubilizing bacteria. The results can be summarized as phosphorus at the level of $15 \mathrm{~kg} \mathrm{P}_{2} \mathrm{O}_{5} \mathrm{fed}^{-1}$ had the highest values of stem length, number of branches/plant, leaves area/plant, dry weight of shoot/plant and total yield $\left(15.39,16.15\right.$ ton $\left.^{f^{-1}}\right)$ and vitamin $\mathrm{C}$. While, the phosphorus level of $30 \mathrm{~kg} \mathrm{P}_{2} \mathrm{O}_{5} \mathrm{fed}^{-1}$ had the highest values of early yield (4.51 and 4.39 ton fed $^{-1}$ ) fruit length, fruit diameter, average fruit weight, TSS, acidity, N\%,K\% in the shoot and fruits. Potassium salicylate spraying had the highest values of stem length, number of branches/plant, leaves area/plant, dry shoot, dry fruit/plant, early and total yield ton fed ${ }^{-1}$, average fruit weight, TSS, acidity, vitamin C and $\mathrm{K} \%$ in fruits. Phosphate solubilizing bacteria inoculation increased stem length, leaves area/plant, dry shoots and fruit weight, early and total yields, fruit length, fruit diameter, average fruit weight, TSS, acidity and vitamin $\mathrm{C}, \mathrm{N} \%, \mathrm{~K} \%$ in the shoot and fruits. Phosphorus at the level $15 \mathrm{~kg} \mathrm{P}_{2} \mathrm{O}_{5}$ fed $^{-1}$ affected curly top virus (TCTV), decreased disease incidence \%, disease severity \% and increased reduction infection \%. Disease severity comparing to the used rating scale (0-4) all the values of $\mathrm{P}$ levels from 12.21 up to $19.95 \%$ lies in class one (11-20\%), this means that effect of P levels on (TCTV) was low. Potassium salicylate spraying decreased disease incidence $\%$, disease severity $\%$ and increased reduction infection $\%$. Comparing with the used rating scale clear that the values of K-salicylate $(4.43,9.75 \%)$ lies in the class zero $(0-10 \%)$, while the control $(21.79,25 \%)$ lies in class two $(21-30 \%)$, this means that Ksalicylate spraying was effective in decreasing (TCTV) in tomato.

Keywords: salicylic acid application, phosphorus fertilizer, biofertilization, tomato curly top virus,

\section{INTRODUCTION}

Tomato (Lycopersicon esculentum Mill) is the most important vegetable crop. It is considered a major vegetable crop in many parts of the world including Egypt. Tomato is a rich source of lycopene and vitamins A and C. Lycopene may help counteract the harmful effects of the free radicals which are thought to contribute to number of types of cancer. Fertilization and plant pathogens are the major factors affect tomato production. Under the Egyptian conditions, only a small part of phosphorus is utilized by plants and the rest is easily precipitated and converted into insoluble fixed forms and this cannot be utilized by the plants.

Phosphorus is an essential component of nucleic acid, phospholipids and energy rich phosphate compounds, thus, it plays crucial role in root growth, fruit and seed development, disease resistance, utilization of sugar and starch and transporting of genetic traits (Khan., 2009). Tesfaye (2008) found that application of $120 \mathrm{~kg} \mathrm{P}_{2} \mathrm{O}_{5} / \mathrm{ha}$, resulted in superior tomato fruit yield, while Qiang and Monica (2017) concluded that $75 \mathrm{~kg} \mathrm{P}_{2} \mathrm{O}_{5}$ /ha was sufficient to grow tomato crop during the winter season in calcareous soil with 13-15 mg kg $\mathrm{kg}^{-1}$ DTPA extractable P. Multinutrients 20/20/20 increased tomato fruit yield, N\% in shoots, N, P and K use efficiency (El-Hamdi., 2011).

Pigna . (2012) reported that phosphorus fertilization plays an important role in alleviating arsenic toxicity in tomato plants. It has allowed to reduce arsenic translocation towards tomato barriers and enhancing plant P status.

Biofertilizers is a substance which contains living microorganisms, when applied to seeds, plant surface or soil, colonizes and promotes growth by increasing the supply or availability of nutrients to the plant. It added nutrients through $\mathrm{N}$ fixation, solubilizing phosphates and stimulating plant growth.

Phosphate solubilizing bacteria in the plant rhizosphere plays a significant role in releasing $\mathrm{P}$ from its insoluble complexes to a form that is more readily usable by plant (Hamissa ., 2000, Nanis ., 2018).

Tomato plants inoculated with phosphate solubilizing bacteria caused an increase in growth in shoots, roots early formation, increased the quality of fruits and seeds (Deepika ., 2013; Sharon ., 2016 and Sreedevi Sarson, 2016).

Turan . (2007) observed that phosphate solubilizing bacteria application converted approximately $20 \%$ of less available $\mathrm{P}$ into labile forms.

Kamil . (2015) stated that, combination of growth promoting bacteria and triple super phosphate had significant effect and increased the yield and growth traits of tomato.

Plant pathogens are responsible for about $15-30 \%$ crop annual losses in Egypt as well as worldwide. Salicylic acid is a plant phenol and today it is in use as internal regulator hormone due to its role in the defensive mechanism against biotic and abiotic stresses (Khan ., 2003).

Virus chemotherapy due to interference with processes which are associated with the initial phases of viral replication or inhibition of virus, specific events that occur during viral maturation and assembly (james ., 1997; Dangl and Jones, 2001 and Leverson ., 2001). Salicylic acid is considered one of the key endogenous signals 
involved in the activation of numerous plant defense responses (Shah and Klessing, 1999 and Hayat ., 2010). Salicylic acid is an important signal molecule in plant that is required for the induction systemic acquired resistance against wide variety of pathogens including fungi, bacteria and virus (Danpsay ., 1999; Kobeasy and Salwa, 2005 and Karban and Chen, 2007). Salicylic acid can enhance the plant growth, yield and quality of tomato (Khodary, 2004 and Javaheri ., 2012).

The objective of the present study is to investigate effect of mineral, bio-phosphorus fertilization and potassium salicylate spraying on tomato growth, yield and yield quality as well as disease severity and incidence of tomato curly top virus (TCTV).

\section{MATERIALS AND METHOS}

Two field experiments were conducted in a private farm at El-Shamarka, Kafr El-Sheikh district, Kafr El-Sheikh governorate during two successive summer seasons of 2014 and 2015. Split split plot design with four replicates was used. The main plots were assigned with three phosphorus fertilizer levels of without, $15 \mathrm{~kg} \mathrm{P}_{2} \mathrm{O}_{5}$ fed $^{-1}$ and $30 \mathrm{~kg} \mathrm{P}_{2} \mathrm{O}_{5} \mathrm{fed}^{-1}$. The sub plots were assigned by two salicylic treatments of without salicylic spraying and spraying with potassium salicylate at the rate of $300 \mathrm{mg} \mathrm{L}^{-1}$ salicylic at spraying solution (Potasal). The sub sub plots were assigned by two biofertilizer treatments of without biofertilizer inoculation, and inoculation with phosphate solubilizing bacteria (Bacilus megatherium). Tomato (Lycopersicon esculentum L.) variety 1077 was used. Seedling transplanted on $5^{\text {th }}$ may in the first season and $7^{\text {th }}$ May in the second season. The micro plot area was $19.5 \mathrm{~m}^{2}$ (3 ridges, $5 \mathrm{~m}$ in length and $1.3 \mathrm{~m}$ in width). Composite soil sample was collected from $(0-30 \mathrm{~cm})$ of the experimental soil, air dried passed through $2 \mathrm{~mm}$ sieve. Soil ECe was determined in soil paste extract, $\mathrm{pH}$ measured in 1:2.5 soil:water suspension, cations and anions were determined in soil paste extract according to Jackson (1967). Particle size distribution, and bulk density were determined according to Black . (1965). Available N, P, $\mathrm{K}$ and $\mathrm{OM}$ were determined according to Cottene . (1982). Some physical and chemical properties of the experimental soil are shown in Table (1).

Table 1. Some physical and chemical properties of the experimental soil

\begin{tabular}{|c|c|c|c|c|c|c|c|c|c|c|c|c|c|c|c|c|c|c|}
\hline \multirow[t]{2}{*}{ Season } & \multicolumn{3}{|c|}{$\begin{array}{l}\text { Particle size } \\
\text { distribution }\end{array}$} & \multirow[t]{2}{*}{ Texture } & \multirow{2}{*}{$\begin{array}{c}\text { OM } \\
\%\end{array}$} & \multirow{2}{*}{$\begin{array}{c}\mathrm{BD} \\
\mathrm{g} / \mathrm{cm}^{3}\end{array}$} & \multirow[t]{2}{*}{ pH } & \multirow{2}{*}{$\begin{array}{l}\text { ECe } \\
\text { dS } / \mathrm{m}\end{array}$} & \multicolumn{4}{|c|}{$\begin{array}{l}\text { Cations } \\
\text { (meq/L) }\end{array}$} & \multicolumn{3}{|c|}{$\begin{array}{c}\text { Anions } \\
(\mathrm{meq} / \mathrm{L})\end{array}$} & \multicolumn{3}{|c|}{ Available nutrients } \\
\hline & Sand & Silt & Clay & & & & & & $\mathrm{Ca}^{++}$ & $\mathbf{M g}^{++}$ & $\mathrm{Na}^{+}$ & $\mathbf{K}^{+}$ & $\mathrm{HCO}_{3}^{-}$ & $\mathrm{Cl}^{-}$ & $\mathrm{SO}_{4}=$ & $\mathbf{N}$ & $\mathbf{P}$ & $\mathbf{K}$ \\
\hline 2014 & 6.6 & 32.5 & 60.9 & Clayey & 1.6 & 1.35 & 7.2 & 2.1 & 10 & 4.0 & 6 & 0.9 & 3.0 & 8.0 & 10 & 27 & 6 & 267 \\
\hline 2015 & 7.0 & 32.5 & 60.5 & Clayey & 1.5 & 1.36 & 7.1 & 2.15 & 9 & 4.0 & 7.2 & 0.7 & 2.5 & 9.0 & 10 & 25 & 5 & 262 \\
\hline
\end{tabular}

BD $=$ Bulk density

Recommended $\mathrm{N}$ was applied as ammonium nitrate $33.5 \%$ in four doses, $\mathrm{P}$ was applied as calcium super phosphate $15.5 \% \quad \mathrm{P}_{2} \mathrm{O}_{5}$ before transplanting and incorporated in the soil, potassium was applied at the recommended dose in one dose with the first irrigation.

Salicylic was sprayed as potassium salicylate $(20 \%$ $\mathrm{K}_{2} \mathrm{O}$ and $12.5 \%$ salicylate) Potasal in the concentration of $300 \mathrm{ppm}$ salicylate, the control (without salicylate) was sprayed by potassium ( $480 \mathrm{ppm})$ equal with the presence of potassium salicylate. Stem length $\mathrm{cm}$, number of branches/plant, leaf area $\left(\mathrm{cm}^{2}\right)$, dry weight of shoots (g/plant), dry weight of fruits (g/plant), early yield (ton/fed.), total yield (ton/fed.), fruit length (cm), fruit diameter (cm), average fruit weight $(\mathrm{g}), \mathrm{TSS} \%$, vitamin $\mathrm{C}$ (mg/100 g fresh weight) and acidity \% were measured. Samples of shoots and fruits were oven dried at $70^{\circ} \mathrm{C}$ and fine ground, wet digested using mixture of sulfuric and perchloric acids. Total N\% was determined by Kjeldahl method, total $\mathrm{K} \%$ was measured by flame photometer according to Jackson (1967). TSS was determined by using the hand refractometer. Vitamin $\mathrm{C}$ was determined by titration as the method mention in AOAC (1990). Also, total titratable acidity was determined according to the method described by AOAC (1990).

Disease incidence $\%$, reduction of infection $\%$ and disease severity $\%$ were evaluated.

Disease severity was evaluated by visual observation of systemic leaf (fourth-fully expanded leaf from the top) following as rating scale of 0-4 as following: $0=$ No symptoms; $0-10 \%$ Infection

$1=$ Vein, clearing after some time; $11-20 \%$

2=Mild stant with curling; 21-30\%
$3=$ Very curling with severe stunting on infected plants; $31-$ $60 \%$

4=Pale leaves, flowering and fruits; $>60 \%$.

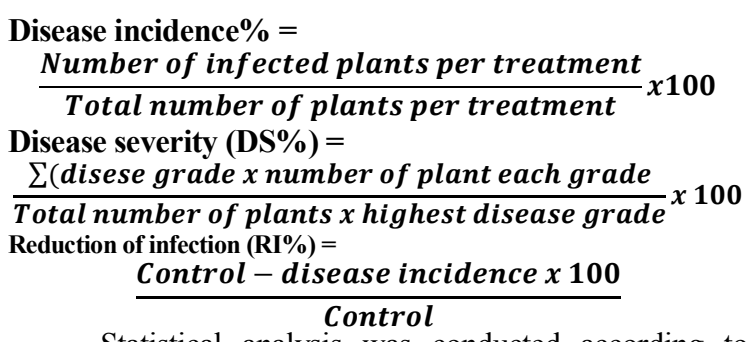

Statistical analysis was conducted according to Snedecor and Cochran (1967).

\section{RESULTS AND DISCUSSION}

Data presented in Table (2) show that phosphorus fertilization levels high significantly affected tomato stem length, number of branches/plant and leaves area/plant in both seasons. The highest values 73.88 and $70.31 \mathrm{~cm}$ of stem length, 15.5 and 13 of number of branches, 11440.3 and $10969.1 \mathrm{~cm}^{2}$ of leaves area/plant in the first and second season, respectively were obtained with the moderate phosphorus level $\left(15 \mathrm{~kg} \mathrm{P}_{2} \mathrm{O}_{5} \mathrm{fed}^{-1}\right)$. The lowest values were obtained with the treatment of without phosphorus fertilization. In respect to salicylic spraying as inducer or antioxidant, spraying led to significantly increases in stem length, number of branches and leaves area per plant in both seasons compared to the treatment without salicylic spraying. Inoculation with phosphate solubilizing bacteria significantly increased tomato stem length and leaves area/plant in both seasons. On the other hand, no 
significant difference in number of branches/plant due to inoculation. The interaction between phosphorus levels and salicylic spraying show $15 \mathrm{~kg} \mathrm{P}_{2} \mathrm{O}_{5}$ and spraying with salicylic had the best stem length, number of branches and leaves area/plant (Table 2). The interaction between phosphorus levels and bioinoculation show that the best treatment of stem length, number of branches and leaves area/plant was $15 \mathrm{~kg} \mathrm{P}_{2} \mathrm{O}_{5} / \mathrm{fed}$. and biofertilizer inoculation in both seasons (Table 2). The interaction between salicylic spraying and biofertilizer inoculation, show the highest values were obtained with salicylic spraying and biofertilizer inoculation (Table 2).

Table 2. Effect of salicylic acid foliar spraying, phosphorus fertilization and inoculation with solubilizing phosphate bacteria and their interaction on stem length, number of branches and leaf area of tomato plant at 70 days after transplanting during the two growing seasons of 2014-2015.

\begin{tabular}{|c|c|c|c|c|c|c|c|c|}
\hline \multicolumn{3}{|c|}{ Treatments } & \multicolumn{2}{|c|}{ Stem length (cm) } & \multicolumn{2}{|c|}{ No. of branches } & \multicolumn{2}{|c|}{ Leaves area/plant $\left(\mathrm{cm}^{2}\right)$} \\
\hline $\begin{array}{l}\text { Phosphorus } \\
\text { levels (kg/fed.) }\end{array}$ & $\begin{array}{l}\text { Salicylic acid } \\
\text { spraying }\end{array}$ & $\begin{array}{c}\text { Inoculation } \\
\text { bacteria }\end{array}$ & $\begin{array}{c}\text { First } \\
\text { season }\end{array}$ & $\begin{array}{c}\text { Second } \\
\text { season }\end{array}$ & $\begin{array}{c}\text { First } \\
\text { season }\end{array}$ & $\begin{array}{c}\text { Second } \\
\text { season }\end{array}$ & $\begin{array}{c}\text { First } \\
\text { season }\end{array}$ & $\begin{array}{l}\text { Second } \\
\text { season }\end{array}$ \\
\hline 30 & & & $65.00 \mathrm{~b}$ & $66.63 \mathrm{~b}$ & $14.56 \mathrm{~b}$ & $12.50 \mathrm{a}$ & $8851.3 \mathrm{~b}$ & $9325.2 \mathrm{~b}$ \\
\hline 0 & & & $64.25 \mathrm{~b}$ & $66.38 \mathrm{~b}$ & $12.63 \mathrm{c}$ & $11.81 \mathrm{~b}$ & $7377.8 \mathrm{c}$ & $8071.7 \mathrm{c}$ \\
\hline 15 & & & $73.88 \mathrm{a}$ & $70.31 \mathrm{a}$ & $15.50 \mathrm{a}$ & $13.00 \mathrm{a}$ & $11440.3 \mathrm{a}$ & $10969.1 \mathrm{a}$ \\
\hline F-test & & & ** & $* *$ & $* *$ & $* *$ & $* *$ & ** \\
\hline \multirow{4}{*}{ F-test } & Spraying & & $69.04 \mathrm{a}$ & 68.00 & $14.54 \mathrm{a}$ & 12.50 & $9588.2 \mathrm{a}$ & $9719.6 \mathrm{a}$ \\
\hline & Without & & $66.88 \mathrm{~b}$ & 67.54 & $13.92 \mathrm{~b}$ & 12.38 & $8858.1 \mathrm{~b}$ & $9191.1 \mathrm{~b}$ \\
\hline & & & ** & NS & ** & NS & ** & ** \\
\hline & & Inoculation & $70.88 \mathrm{a}$ & $69.42 \mathrm{a}$ & 14.33 & 12.50 & $10059.1 \mathrm{a}$ & $9782.4 \mathrm{a}$ \\
\hline F-test & & Without & $\begin{array}{c}65.04 \mathrm{~b} \\
* *\end{array}$ & $\begin{array}{c}66.13 \mathrm{~b} \\
* *\end{array}$ & $\begin{array}{c}14.13 \\
\text { NS }\end{array}$ & $\begin{array}{c}12.38 \\
\text { NS }\end{array}$ & $\begin{array}{c}8387.2 \mathrm{~b} \\
* *\end{array}$ & $\begin{array}{c}9128.2 \mathrm{~b} \\
* *\end{array}$ \\
\hline \multirow{2}{*}{30} & Spraying & & $64.38 \mathrm{~d}$ & 66.00 & $14.50 \mathrm{bc}$ & 12.13 & $8818.0 \mathrm{c}$ & $9326.0 \mathrm{c}$ \\
\hline & Without & & $65.13 \mathrm{~cd}$ & 67.25 & $14.63 \mathrm{a}$ & 12.88 & $8884.5 \mathrm{c}$ & $9324.4 \mathrm{c}$ \\
\hline \multirow{2}{*}{0} & Spraying & & $66.13 \mathrm{c}$ & 67.00 & $13.38 \mathrm{bc}$ & 12.13 & $7810.4 \mathrm{~d}$ & $8373.6 \mathrm{~d}$ \\
\hline & Without & & $64.38 \mathrm{~d}$ & 65.75 & $11.88 \mathrm{c}$ & 11.50 & $6945.2 \mathrm{e}$ & $7769.8 \mathrm{e}$ \\
\hline \multirow{2}{*}{15} & Spraying & & $76.63 \mathrm{a}$ & 71.00 & $15.75 \mathrm{a}$ & 13.25 & $12136.2 \mathrm{a}$ & $11459.0 \mathrm{a}$ \\
\hline & Without & & $71.13 \mathrm{~b}$ & 69.63 & $15.25 \mathrm{ab}$ & 12.75 & $10744.5 \mathrm{~b}$ & $10479.2 \mathrm{~b}$ \\
\hline$\underline{F-t e s t}$ & & & $* *$ & NS & $* *$ & NS & $* *$ & $* *$ \\
\hline \multirow{2}{*}{30} & & Inoculation & $64.25 \mathrm{~d}$ & $65.63 \mathrm{c}$ & $13.63 \mathrm{c}$ & $11.88 \mathrm{~cd}$ & $8172.9 \mathrm{~d}$ & $9022.8 \mathrm{~cd}$ \\
\hline & & Without & $65.25 \mathrm{c}$ & $67.63 \mathrm{~b}$ & $15.50 \mathrm{ab}$ & $13.13 \mathrm{ab}$ & $9529.7 \mathrm{~b}$ & $9627.5 \mathrm{bcd}$ \\
\hline \multirow{2}{*}{0} & & Inoculation & $66.88 \mathrm{~b}$ & $67.75 \mathrm{~b}$ & $13.38 \mathrm{c}$ & $12.33 \mathrm{bc}$ & $8055.3 \mathrm{~d}$ & $8343.0 \mathrm{bc}$ \\
\hline & & Without & $63.63 \mathrm{~d}$ & $65.00 \mathrm{c}$ & $11.88 \mathrm{~d}$ & $11.25 \mathrm{~d}$ & $6700.4 \mathrm{e}$ & $7800.5 \mathrm{e}$ \\
\hline \multirow{2}{*}{15} & & Inoculation & $81.50 \mathrm{a}$ & $64.88 \mathrm{a}$ & $16.00 \mathrm{a}$ & $13.25 \mathrm{a}$ & $13949.3 \mathrm{a}$ & $11981.5 \mathrm{a}$ \\
\hline & & Without & $66.25 \mathrm{~b}$ & $65.75 \mathrm{c}$ & $15.00 \mathrm{~b}$ & $12.75 \mathrm{ab}$ & $8931.4 \mathrm{c}$ & $9956.7 \mathrm{~b}$ \\
\hline \multirow[t]{5}{*}{ F-test } & & & $* *$ & $* *$ & ** & $* *$ & $* *$ & $* *$ \\
\hline & & Inoculation & $72.33 \mathrm{a}$ & 69.33 & $15.00 \mathrm{a}$ & 12.67 & $10777.4 \mathrm{a}$ & $10233.5 \mathrm{a}$ \\
\hline & Spr & Without & $65.75 \mathrm{c}$ & 66.67 & $14.08 \mathrm{~b}$ & 12.33 & $8398.6 \mathrm{c}$ & 9205.9 a \\
\hline & Without & Inoculation & $69.42 \mathrm{~b}$ & 69.50 & $13.67 \mathrm{~b}$ & 12.33 & $9340.4 \mathrm{~b}$ & $9331.4 \mathrm{a}$ \\
\hline & Without & Without & $64.33 \mathrm{~d}$ & 65.58 & $14.17 \mathrm{~b}$ & 12.42 & $8375.7 \mathrm{c}$ & $9050.9 \mathrm{~b}$ \\
\hline F-test & & & $* *$ & NS & $* *$ & NS & ** & $* *$ \\
\hline \multirow{4}{*}{30} & Snraving & Inoculation & $64.00 \mathrm{f}$ & 64.75 & 14.25 & 11.50 & 8705.5 & $9437.5 \mathrm{e}$ \\
\hline & Spraying & Without & $64.75 \mathrm{ef}$ & 67.25 & 14.75 & 12.75 & 8930.6 & $9214.6 \mathrm{e}$ \\
\hline & With & Inoculation & $64.50 \mathrm{f}$ & 64.75 & 13.00 & 12.25 & 7640.2 & $8608.2 \mathrm{f}$ \\
\hline & Without & Without & $65.75 \mathrm{df}$ & 67.25 & 16.25 & 13.50 & 10128.8 & $10040.5 \mathrm{~d}$ \\
\hline \multirow{4}{*}{0} & Snravino & Inoculation & $67.25 \mathrm{c}$ & 68.00 & 14.25 & 12.75 & 8782.7 & $8780.5 \mathrm{f}$ \\
\hline & spraying & Without & $65.00 \mathrm{ef}$ & 66.00 & 12.50 & 11.50 & 6838.2 & $7966.8 \mathrm{~g}$ \\
\hline & Without & Inoculation & $66.50 \mathrm{~cd}$ & 67.50 & 12.50 & 12.00 & 7327.9 & $7905.4 \mathrm{~g}$ \\
\hline & Without & Without & $62.25 \mathrm{~g}$ & 64.00 & 11.25 & 11.00 & 6562.6 & $7634.1 \mathrm{f}$ \\
\hline \multirow{4}{*}{15} & & Inoculation & $85.75 \mathrm{a}$ & 75.25 & 16.50 & 13.75 & 14845.4 & $12482.5 \mathrm{a}$ \\
\hline & Spraying & Without & $67.50 \mathrm{c}$ & 66.75 & 15.00 & 12.75 & 9427.1 & $10435.6 \mathrm{c}$ \\
\hline & Without & Inoculation & $77.25 \mathrm{~b}$ & 74.75 & 15.00 & 12.75 & 13053.2 & $11480.5 \mathrm{~b}$ \\
\hline & Without & Without & $65.00 \mathrm{ef}$ & 64.50 & 15.00 & 12.75 & 8435.8 & 9477.9 e \\
\hline F-test & & & $* *$ & $\mathrm{NS}$ & NS & NS & NS & $* *$ \\
\hline
\end{tabular}

**, * and NS indicate significant differences at $\mathrm{P}<0.01,<0.05$ and not significant, respectively according to $\mathrm{F}$-test.

In the same column, means followed by the same letter are not significantly different at $5 \%$ level according to Duncan's test.

Data in Table (3) show that phosphorus fertilization levels high significantly affected tomato dry weight of shoot and fruits per plant in both seasons. The
The interaction between phosphorus levels, ic spraying and biofertilizer inoculation show that $\mathrm{fed}^{-1}+$ salicylic spraying + bioinoculation (Table 2). The previous data may be due to available $\mathrm{P}$ in the soil before transplanting was less than plant need and application of $\mathrm{P}$ fertilizer and $\mathrm{P}$ solubilizing bacteria increased their availability. These results are in agreement with those (2009) and Sharon . (2016). Salicylic acid may induce resistance against biotic and abiotic stress, these results enhanced by Kobeasy and Salwa El-Hamid (2005). highest dry shoot values were obtained with $15 \mathrm{~kg} \mathrm{P}_{2} \mathrm{O}_{5}$ $\mathrm{fed}^{-1}$ (240.5 and $\left.235.69 \mathrm{~g} / \mathrm{plant}\right)$. While the highest dry fruit weight values were obtained with $30 \mathrm{~kg} \mathrm{P}_{2} \mathrm{O}_{5}$ fed $^{-1}$ 
(6.1 and $6.1 \mathrm{~g} / \mathrm{plant}$ ) in the first and second seasons, respectively. On the other hand, the lowest values were recorded with zero phosphorus. These results are in harmony with those obtained by Deepika Divya Kadiri . (2013). Spraying salicylic acid high significantly increased tomato dry shoot and fruits per plant (226.91, 209.85) and (5.9, $5.94 \mathrm{~g} /$ plant) compared to the treatment without salicylic spraying $(213.78,198.3)$ and $(5.53,5.64)$. These results are in harmony with those obtained by Khodary (2004). Inoculation with phosphate solubilizing bacteria high significantly

Table 3. Effect of salicylic acid foliar spraying, phosphorus fertilization and inoculation with solubilizing phosphate bacteria and their interaction on dry weight of shoot and dry matter of tomato fruits in the two growing seasons 2014-2015.

\begin{tabular}{|c|c|c|c|c|c|c|}
\hline \multicolumn{3}{|c|}{ Treatments } & \multicolumn{2}{|c|}{ Dry weight of shoot (g/plant) } & \multicolumn{2}{|c|}{ Dry matter of fruits (g/plant) } \\
\hline $\begin{array}{l}\text { Phosphorus } \\
\text { levels (kg/fed.) }\end{array}$ & $\begin{array}{l}\text { Salicylic acid } \\
\text { spraying }\end{array}$ & $\begin{array}{c}\text { Inoculation } \\
\text { bacteria }\end{array}$ & $\begin{array}{c}\text { First } \\
\text { season }\end{array}$ & $\begin{array}{l}\text { Second } \\
\text { season }\end{array}$ & $\begin{array}{r}\text { First } \\
\text { season }\end{array}$ & $\begin{array}{l}\text { Second } \\
\text { season }\end{array}$ \\
\hline 30 & & & $219.47 b$ & $200.52 b$ & $6.10 \mathrm{a}$ & $6.10 \mathrm{a}$ \\
\hline 0 & & & $201.10 \mathrm{c}$ & $176.01 \mathrm{c}$ & $5.43 \mathrm{c}$ & $5.56 \mathrm{c}$ \\
\hline 15 & & & $240.50 \mathrm{a}$ & $235.69 \mathrm{a}$ & $5.62 \mathrm{~b}$ & $5.80 \mathrm{~b}$ \\
\hline F-test & & & $* *$ & $* *$ & $* *$ & $* *$ \\
\hline \multirow[b]{3}{*}{ F-test } & Spraying & & $226.91 \mathrm{a}$ & $209.85 \mathrm{a}$ & $5.90 \mathrm{a}$ & $5.94 \mathrm{a}$ \\
\hline & Without & & $213.78 \mathrm{~b}$ & $198.30 \mathrm{~b}$ & $5.53 \mathrm{~b}$ & $5.64 \mathrm{~b}$ \\
\hline & & & $* *$ & $* *$ & ** & $* *$ \\
\hline \multirow[b]{3}{*}{ F-test } & & Inoculation & $226.65 \mathrm{a}$ & $213.86 \mathrm{a}$ & $6.09 \mathrm{a}$ & $6.08 \mathrm{a}$ \\
\hline & & Without & $215.04 \mathrm{~b}$ & $194.28 \mathrm{~b}$ & $5.34 \mathrm{~b}$ & $5.50 \mathrm{~b}$ \\
\hline & & & $* *$ & $* *$ & $* *$ & $* *$ \\
\hline \multirow{2}{*}{30} & Spraying & & $219.98 \mathrm{c}$ & $200.29 \mathrm{c}$ & 6.24 & 6.14 \\
\hline & Without & & $218.96 \mathrm{c}$ & $200.75 \mathrm{c}$ & 5.96 & 5.89 \\
\hline \multirow{2}{*}{0} & Spraying & & $206.31 \mathrm{~d}$ & $182.58 \mathrm{~d}$ & 5.64 & 5.65 \\
\hline & Without & & $195.83 \mathrm{e}$ & $169.44 \mathrm{e}$ & 5.21 & 5.46 \\
\hline \multirow{2}{*}{15} & Spraying & & $254.45 \mathrm{a}$ & $246.68 \mathrm{a}$ & 5.83 & 6.03 \\
\hline & Without & & $226.55 b$ & $224.70 \mathrm{~b}$ & 5.41 & 5.58 \\
\hline F-test & & & $* *$ & $* *$ & NS & NS \\
\hline \multirow{2}{*}{30} & & Inoculation & $205.86 \mathrm{~d}$ & $188.83 \mathrm{~d}$ & $6.63 \mathrm{a}$ & $6.40 \mathrm{a}$ \\
\hline & & Without & $223.08 \mathrm{~b}$ & $212.21 \mathrm{~b}$ & $5.58 \mathrm{~d}$ & $5.61 \mathrm{c}$ \\
\hline \multirow{2}{*}{0} & & Inoculation & $206.84 \mathrm{~d}$ & $184.65 \mathrm{e}$ & $5.70 \mathrm{c}$ & $5.75 \mathrm{c}$ \\
\hline & & Without & $19530 \mathrm{e}$ & $167.36 \mathrm{f}$ & $5.15 \mathrm{f}$ & $5.36 \mathrm{~d}$ \\
\hline \multirow{2}{*}{15} & & Inoculation & $267.27 \mathrm{a}$ & $268.10 \mathrm{a}$ & $5.95 \mathrm{~b}$ & $6.09 \mathrm{~b}$ \\
\hline & & Without & $213.74 \mathrm{c}$ & $203.28 \mathrm{c}$ & $5.29 \mathrm{e}$ & $5.51 \mathrm{c}$ \\
\hline \multirow[t]{6}{*}{ F-test } & & & ** & $* *$ & $* *$ & $*$ \\
\hline & & Inoculation & $236.57 \mathrm{a}$ & $223.92 \mathrm{a}$ & 6.30 & $6.16 \mathrm{a}$ \\
\hline & spraying & Without & $217.08 \mathrm{~b}$ & $195.78 \mathrm{c}$ & 5.50 & $5.72 \mathrm{~b}$ \\
\hline & Withos & Inoculation & $216.57 \mathrm{~b}$ & $203.80 \mathrm{~b}$ & 588 & $6.00 \mathrm{a}$ \\
\hline & Writnout & Without & $210.99 \mathrm{c}$ & $192.79 \mathrm{~d}$ & 5.18 & $5.28 \mathrm{c}$ \\
\hline & F-test & & ** & $* *$ & NS & $*$ \\
\hline \multirow{4}{*}{30} & Snraving & Inoculation & $211.93 \mathrm{e}$ & 191.73 & 6.78 & 6.50 \\
\hline & spraying & Without & $228.03 \mathrm{~d}$ & 208.85 & 5.70 & 5.78 \\
\hline & Without & Inoculation & $199.80 \mathrm{f}$ & 185.93 & 6.48 & 6.30 \\
\hline & vilitedit & Without & $238.13 \mathrm{c}$ & 215.58 & 5.45 & 5.45 \\
\hline \multirow{4}{*}{0} & Snraving & Inoculation & $216.60 \mathrm{e}$ & 196.20 & 5.98 & 5.78 \\
\hline & Spiayilis & Without & $196.03 \mathrm{f}$ & 168.95 & 5.30 & 5.53 \\
\hline & & Inoculation & $197.08 \mathrm{f}$ & 173.10 & 5.43 & 5.73 \\
\hline & Without & Without & $194.58 \mathrm{f}$ & 165.78 & 5.00 & 5.20 \\
\hline \multirow{4}{*}{15} & Spraving & Inoculation & $281.70 \mathrm{a}$ & 283.83 & 6.15 & 6.20 \\
\hline & spraymg & Without & $227.20 \mathrm{~d}$ & 209.53 & 5.50 & 5.85 \\
\hline & Without & Inoculation & $252.83 \mathrm{~b}$ & 252.38 & 5.75 & 5.98 \\
\hline & vitiovet & Without & $200.28 \mathrm{f}$ & 197.03 & 5.08 & 5.18 \\
\hline F-test & & & $* *$ & NS & NS & NS \\
\hline
\end{tabular}

**, * and NS indicate significant differences at $\mathrm{P}<\mathbf{0 . 0 1},<0.05$ and not significant, respectively according to $\mathrm{F}$-test.

In the same column, means followed by the same letter are not significantly different at $5 \%$ level according to Duncan's test.

The interaction between phosphorus levels and bioinoculation (Table 3) show high significantly increase in dry shoot and fruits weight/plant. The highest values were observed with $15 \mathrm{~kg} \mathrm{p} 2 \mathrm{O} 5$ + bio-inoculation in shoot weight, while in dry fruit weight the highest values with 30 $\mathrm{kg} \mathrm{P}_{2} \mathrm{O}_{5}+$ bio inoculation. The interaction between increased dry shoot and fruits per plant $(226.65,213.86)$ and $(6.09,6.08)$ compared to $(215.04,194.28)$ and $(5.34,5.5) \mathrm{g} / \mathrm{plant}$ in the first and second seasons, respectively. These results are in agreement with those obtained by Sreedevi Sarsan (2016). The interaction effect between phosphorus levels and salicylic spraying was highly significant on tomato dry shoot weight (g/plant), where the highest values were obtained with $15 \mathrm{~kg} \mathrm{P}_{2} \mathrm{O}_{5}+$ salicylic spraying. On the other hand, no significant differences in fruit dry weight were detected. 
highest early yield $(4.51,4.39)$ ton fed $^{-1}$ were obtained with $30 \mathrm{~kg} \mathrm{P}_{2} \mathrm{O}_{5}$ fed $^{-1}$ in the first and second seasons, respectively. The highest total yield $(15.38,16.15)$ ton fed $^{-1}$ were obtained with $15 \mathrm{~kg} \mathrm{P}_{2} \mathrm{O}_{5}$ fed $^{-1}$ in the first and second seasons, respectively. On the other hand the lowest values were recorded with the treatment without phosphorus application.

Table 4. Effect of salicylic acid foliar spraying, phosphorus fertilization and inoculation with solubilizing phosphate bacteria and their interaction on early and total yield of tomato in the two growing seasons 2014-2015.

\begin{tabular}{|c|c|c|c|c|c|c|}
\hline \multicolumn{3}{|c|}{ Treatments } & \multicolumn{2}{|c|}{ Early yield (ton/fed.) } & \multicolumn{2}{|c|}{ Total yield (ton/fed) } \\
\hline $\begin{array}{l}\text { Phosphorus } \\
\text { levels (kg/fed.) }\end{array}$ & $\begin{array}{l}\text { Salicylic acid } \\
\text { spraying }\end{array}$ & $\begin{array}{c}\text { Inoculation } \\
\text { bacteria }\end{array}$ & $\begin{array}{c}\text { First } \\
\text { season }\end{array}$ & $\begin{array}{l}\text { Second } \\
\text { season }\end{array}$ & $\begin{array}{c}\text { First } \\
\text { season }\end{array}$ & $\begin{array}{l}\text { Second } \\
\text { season }\end{array}$ \\
\hline 30 & & & $4.514 \mathrm{a}$ & $4.393 \mathrm{a}$ & $13.818 \mathrm{~b}$ & $14.359 \mathrm{~b}$ \\
\hline 0 & & & $2.535 \mathrm{c}$ & $2.357 \mathrm{c}$ & $11.742 \mathrm{c}$ & $12.657 \mathrm{c}$ \\
\hline 15 & & & $4.055 \mathrm{~b}$ & $3.850 \mathrm{~b}$ & $15.385 \mathrm{a}$ & $16.150 \mathrm{a}$ \\
\hline F-test & & & $* *$ & $* *$ & $* *$ & $* *$ \\
\hline \multirow[b]{3}{*}{ F-test } & Spraying & & $3.899 \mathrm{a}$ & $3.636 \mathrm{a}$ & $14.298 \mathrm{a}$ & $15.037 \mathrm{a}$ \\
\hline & Without & & $3.504 \mathrm{~b}$ & $3.430 \mathrm{~b}$ & $12.999 \mathrm{~b}$ & $13.741 \mathrm{~b}$ \\
\hline & & & $* *$ & $* *$ & ** & ** \\
\hline \multirow[b]{3}{*}{ F-test } & & Inoculation & $3.793 \mathrm{a}$ & $3.628 \mathrm{a}$ & $13.781 \mathrm{a}$ & $14.470 \mathrm{a}$ \\
\hline & & Without & $3.610 \mathrm{~b}$ & $3.439 \mathrm{~b}$ & $13.516 b$ & $14.307 \mathrm{~b}$ \\
\hline & & & $* *$ & ** & ** & $*$ \\
\hline \multirow{2}{*}{30} & Spraying & & 4.673 & 4.405 & $14.288 \mathrm{c}$ & $14.707 \mathrm{c}$ \\
\hline & Without & & 4.356 & 4.380 & $13.349 \mathrm{~d}$ & $14.011 \mathrm{~d}$ \\
\hline \multirow{2}{*}{0} & Spraying & & 2.709 & 2.494 & $12.589 \mathrm{e}$ & $13.489 \mathrm{e}$ \\
\hline & Without & & 2.362 & 2.221 & $10.896 \mathrm{f}$ & $11.824 \mathrm{f}$ \\
\hline \multirow{2}{*}{15} & Spraying & & 4.315 & 4.010 & $16.019 \mathrm{a}$ & $16.914 \mathrm{a}$ \\
\hline & Without & & 3.795 & 3.691 & $14.752 \mathrm{~b}$ & $15.386 \mathrm{~b}$ \\
\hline F-test & & & NS & NS & $* *$ & $* *$ \\
\hline \multirow{2}{*}{30} & & Inoculation & $4.552 \mathrm{a}$ & $4.419 \mathrm{a}$ & $12.994 \mathrm{c}$ & $13.582 \mathrm{~d}$ \\
\hline & & Without & $4.477 \mathrm{~b}$ & $4.366 \mathrm{a}$ & $14.643 \mathrm{~b}$ & $15.136 \mathrm{c}$ \\
\hline \multirow{2}{*}{0} & & Inoculation & $2.623 \mathrm{e}$ & $2.425 \mathrm{~d}$ & $12.216 \mathrm{~d}$ & $13.101 \mathrm{e}$ \\
\hline & & Without & $2.448 \mathrm{f}$ & $2.290 \mathrm{e}$ & $11.269 \mathrm{e}$ & $12.213 \mathrm{f}$ \\
\hline \multirow{2}{*}{15} & & Inoculation & $4.284 \mathrm{c}$ & $4.040 \mathrm{~b}$ & $16.133 \mathrm{a}$ & $16.728 \mathrm{a}$ \\
\hline & & Without & $3.826 \mathrm{~d}$ & $3.661 \mathrm{c}$ & $14.637 \mathrm{~b}$ & $15.572 \mathrm{~b}$ \\
\hline \multirow[t]{5}{*}{ F-test } & & & ** & ** & $* *$ & ** \\
\hline & & Inoculation & 3.992 & $3.810 \mathrm{a}$ & 14.476 & 15.126 \\
\hline & Spraying & Without & 3.806 & $3.462 \mathrm{~b}$ & 14.121 & 14.947 \\
\hline & Without & Inoculation & 3.594 & $3.445 \mathrm{~b}$ & 13.087 & 13.815 \\
\hline & Without & Without & 3.414 & $3.416 \mathrm{~b}$ & 12.911 & 13.667 \\
\hline F-test & & & NS & $* *$ & NS & NS \\
\hline \multirow{4}{*}{30} & Snraving & Inoculation & $4.723 \mathrm{a}$ & $4.786 \mathrm{a}$ & $14.133 \mathrm{f}$ & $14.320 \mathrm{e}$ \\
\hline & spraying & Without & $4.623 \mathrm{~b}$ & $4.025 \mathrm{~b}$ & $14.442 \mathrm{e}$ & $15.095 \mathrm{~d}$ \\
\hline & Without & Inoculation & $4.221 \mathrm{~d}$ & $4.052 \mathrm{~b}$ & $11.855 \mathrm{j}$ & $12.845 \mathrm{~g}$ \\
\hline & vilitiout & Without & $4.491 \mathrm{c}$ & $4.707 \mathrm{a}$ & $14.843 \mathrm{~d}$ & $15.178 \mathrm{~d}$ \\
\hline \multirow{4}{*}{0} & Snravino & Inoculation & $2.780 \mathrm{~g}$ & $2.544 \mathrm{~d}$ & $12.940 \mathrm{~h}$ & $13.880 \mathrm{f}$ \\
\hline & Spiayiltg & Without & $2.638 \mathrm{~h}$ & $2.443 \mathrm{de}$ & $12.237 \mathrm{i}$ & $13.099 \mathrm{~g}$ \\
\hline & Without & Inoculation & $2.467 \mathrm{i}$ & $2.305 \mathrm{ef}$ & $11.492 \mathrm{k}$ & $12.321 \mathrm{~h}$ \\
\hline & Without & Without & $2.257 \mathrm{j}$ & $2.137 \mathrm{f}$ & $10.300 \mathrm{~L}$ & $11.327 \mathrm{i}$ \\
\hline \multirow{4}{*}{15} & Spraving & Inoculation & $4.472 \mathrm{c}$ & $4.101 \mathrm{~b}$ & $16.353 \mathrm{a}$ & $17.179 \mathrm{a}$ \\
\hline & spraying & Without & $4.185 \mathrm{de}$ & $3.919 b$ & $15.684 \mathrm{c}$ & $16.649 \mathrm{~b}$ \\
\hline & & Inoculation & $4.095 \mathrm{e}$ & $3.979 \mathrm{~b}$ & $15.913 b$ & $16.277 \mathrm{c}$ \\
\hline & Without & Without & $3.495 \mathrm{f}$ & $3.402 \mathrm{c}$ & $13.591 \mathrm{~g}$ & $14.795 \mathrm{e}$ \\
\hline F-test & & & ** & ** & $* *$ & ** \\
\hline
\end{tabular}

**, * and NS indicate significant differences at $\mathrm{P}<0.01,<0.05$ and not significant, respectively according to $\mathrm{F}$-test.

In the same column, means followed by the same letter are not significantly different at $5 \%$ level according to Duncan's test.

Spraying with salicylic led to high significantly increase of early and total yields ton $\mathrm{fed}^{-1}$ in both seasons, compared to without spraying one. Phosphate solubilizing bacteria inoculation high significantly increased early and total tomato yields $(3.79,3.63)$ and $(13.78,14.47)$ ton $\mathrm{fed}^{-1}$ compared with $(3.61,3.44)$ and $(13.52,14.31)$ ton $\mathrm{fed}^{-1}$ in the control. These results are in agreement with those obtained by Tesfaye (2008) who concluded that phosphorus application resulted in superior tomato fruit yield.

Javaheri . (2012) reported that application of salicylic acid had higher fruit yield of tomato. Kamil . (2015) found that combination treatment of biofertilizer and chemical fertilizer increased the yield and growth of tomato. The interaction between phosphorus levels and salicylic spraying had no significant effect on early yield and high significantly increased total tomato yield. The highest total yield values were with $15 \mathrm{~kg} \mathrm{P}_{2} \mathrm{O}_{5}+$ salicylic spraying. The interaction between phosphorus levels and bio inoculation show that early yield high significantly increased with $30 \mathrm{~kg} \mathrm{P}_{2} \mathrm{O}_{5} \mathrm{fed}^{-1}+$ bio inoculation, while the total yield high significantly increased with $15 \mathrm{~kg} \mathrm{P}_{2} \mathrm{O}_{5}+$ bio inoculation.

The interaction between phosphorus levels, salicylic spraying and bioinoculation show that the best treatment for early yield was $30 \mathrm{~kg} \mathrm{P}_{2} \mathrm{O}_{5}+$ salicylic 
spraying + bioinoculation. While the best treatment for the total yield was $15 \mathrm{~kg} \mathrm{P}_{2} \mathrm{O}_{5} \mathrm{fed}^{-1}+$ salicylic spraying + bio inoculation.

Data tabulated in Table (5) show that, tomato fruit length, fruit diameter and average fruit weight high significantly affected by phosphorus levels in both seasons. The highest fruit length $(7.41,7.13 \mathrm{~cm})$, high fruit diameter (5.48, 5.44) and highest average fruit weight (108.58, $109.81) \mathrm{g}$ /fruit were obtained with $30 \mathrm{~kg} \mathrm{P}_{2} \mathrm{O}_{5} \mathrm{fed}^{-1}$ in the first and second seasons, respectively. On the other hand, the lowest values were observed with the control (without phosphorus treatment). These results are in line with those obtained by Qiang and Monica (2017). Spraying tomato with salicylic high significantly increased average fruit weight $(102.0,105.75 \mathrm{~g} /$ fruit) in the first and second seasons, respectively compared with $(93.01,94.53)$. These results are in line with Hayat . (2010). Data in Table (5) show that biofertilizer inoculation high significantly increased fruit length, fruit diameter and average fruit weight in both seasons compared to uninoculated one. These results are in harmony with those obtained by Sreedevi Sarsan (2016).

Table 5. Effect of salicylic acid foliar spraying, phosphorus fertilization and inoculation with solubilizing phosphate bacteria and their interaction on fruit physical quality of tomato during the two growing seasons of 2014-2015.

\begin{tabular}{|c|c|c|c|c|c|c|c|c|}
\hline \multicolumn{3}{|c|}{ Treatments } & \multicolumn{2}{|c|}{ Fruit length (cm) } & \multicolumn{2}{|c|}{ Fruit diameter $(\mathrm{cm})$} & \multicolumn{2}{|c|}{ Av. Fruit weight (g/fruit) } \\
\hline $\begin{array}{l}\text { Phosphorus } \\
\text { levels (kg/fed.) }\end{array}$ & $\begin{array}{c}\text { Salicylic acid } \\
\text { spraying }\end{array}$ & $\begin{array}{c}\text { Inoculation } \\
\text { bacteria }\end{array}$ & $\begin{array}{c}\text { First } \\
\text { season }\end{array}$ & $\begin{array}{c}\text { Second } \\
\text { season }\end{array}$ & $\begin{array}{c}\text { First } \\
\text { season }\end{array}$ & $\begin{array}{c}\text { Second } \\
\text { season }\end{array}$ & $\begin{array}{c}\text { First } \\
\text { season }\end{array}$ & $\begin{array}{l}\text { Second } \\
\text { season }\end{array}$ \\
\hline$\overline{30}$ & & & $7.41 \mathrm{a}$ & $7.13 \mathrm{a}$ & $5.48 \mathrm{a}$ & $5.44 \mathrm{a}$ & $108.58 \mathrm{a}$ & $109.81 \mathrm{a}$ \\
\hline 0 & & & $6.08 \mathrm{c}$ & $6.40 \mathrm{c}$ & $5.11 \mathrm{c}$ & $5.23 \mathrm{~b}$ & $83.38 \mathrm{c}$ & $84.81 \mathrm{c}$ \\
\hline 15 & & & $7.13 \mathrm{~b}$ & $6.93 \mathrm{~b}$ & $5.45 \mathrm{~b}$ & $5.45 \mathrm{a}$ & $100.56 \mathrm{~b}$ & $105.70 \mathrm{~b}$ \\
\hline F-test & & & $* *$ & $* *$ & $* *$ & $* *$ & $* *$ & $* *$ \\
\hline \multirow[b]{3}{*}{ F-test } & Spraying & & $6.996 \mathrm{~b}$ & 6.93 & $5.40 \mathrm{a}$ & 5.38 & $102.00 \mathrm{a}$ & $105.75 \mathrm{a}$ \\
\hline & Without & & $7.167 \mathrm{a}$ & 6.98 & $5.23 \mathrm{~b}$ & 5.37 & $93.01 \mathrm{~b}$ & $94.53 b$ \\
\hline & & & $*$ & NS & ** & NS & $* *$ & ** \\
\hline \multirow[b]{3}{*}{ F-test } & & Inoculation & $7.24 \mathrm{a}$ & $6.98 \mathrm{a}$ & $5.47 \mathrm{a}$ & $5.43 \mathrm{a}$ & $100.86 \mathrm{a}$ & $103.18 \mathrm{~g}$ \\
\hline & & Without & $6.92 \mathrm{~b}$ & $6.66 \mathrm{~b}$ & $5.23 \mathrm{~b}$ & $5.32 \mathrm{~b}$ & $94.15 \mathrm{~b}$ & $97.09 \mathrm{~b}$ \\
\hline & & & $* *$ & $* *$ & $* *$ & $* *$ & ** & $* *$ \\
\hline \multirow{2}{*}{30} & Spraying & & 7.35 & 6.98 & 5.53 & 5.43 & 108.74 & $111.36 \mathrm{~b}$ \\
\hline & Without & & 7.48 & 7.29 & 5.43 & 5.46 & 108.43 & $108.25 \mathrm{~b}$ \\
\hline \multirow{2}{*}{0} & Spraying & & 6.51 & 6.48 & 5.15 & 5.24 & 89.25 & $89.53 \mathrm{~d}$ \\
\hline & Without & & 6.89 & 6.33 & 5.06 & 5.21 & 77.54 & $80.29 \mathrm{e}$ \\
\hline \multirow{2}{*}{15} & Spraying & & 7.13 & 7.04 & 5.54 & 5.48 & 108.04 & $116.35 \mathrm{a}$ \\
\hline & Without & & 7.14 & 6.83 & 5.63 & 5.43 & 93.08 & $95.05 \mathrm{c}$ \\
\hline F-test & & & NS & NS & NS & NS & NS & ** \\
\hline \multirow{2}{*}{30} & & Inoculation & 7.55 & $7.28 \mathrm{a}$ & 5.63 & $5.54 \mathrm{a}$ & $116.43 \mathrm{a}$ & $117.83 \mathrm{a}$ \\
\hline & & Without & 7.28 & $6.99 \mathrm{~b}$ & 5.33 & $5.35 \mathrm{c}$ & $100.74 \mathrm{~b}$ & $101.79 \mathrm{c}$ \\
\hline \multirow{2}{*}{0} & & Inoculation & 6.94 & $6.48 \mathrm{~d}$ & 5.21 & $5.30 \mathrm{c}$ & $87.05 \mathrm{c}$ & $86.65 \mathrm{~d}$ \\
\hline & & Without & 6.46 & $6.33 \mathrm{~d}$ & 5.00 & $5.15 \mathrm{~d}$ & $79.71 \mathrm{c}$ & $83.16 \mathrm{e}$ \\
\hline \multirow{2}{*}{15} & & Inoculation & 7.24 & $7.19 \mathrm{a}$ & 5.58 & $5.44 \mathrm{~b}$ & $99.11 \mathrm{~b}$ & $105.08 \mathrm{~b}$ \\
\hline & & Without & 7.03 & $6.68 \mathrm{c}$ & 5.33 & $5.46 \mathrm{~b}$ & $102.00 \mathrm{~b}$ & $106.33 \mathrm{~b}$ \\
\hline \multirow[t]{5}{*}{ F-test } & & & NS & $* *$ & NS & ** & ** & ** \\
\hline & & Inoculation & 7.21 & 6.95 & 5.52 & $5.46 \mathrm{a}$ & 104.77 & $106.69 \mathrm{a}$ \\
\hline & Spraying & Without & 6.78 & 6.71 & 5.29 & $5.30 \mathrm{c}$ & 99.23 & $104.80 \mathrm{~b}$ \\
\hline & Without & Inoculation & 7.23 & 7.01 & 5.43 & $5.39 \mathrm{~b}$ & 96.96 & $99.68 \mathrm{c}$ \\
\hline & Williout & Without & 7.06 & 6.62 & 5.14 & $5.34 \mathrm{bc}$ & 89.07 & $89.38 \mathrm{~d}$ \\
\hline F-test & & & NS & NS & NS & $* *$ & NS & $* *$ \\
\hline \multirow{4}{*}{30} & Snraving & Inoculation & 7.60 & 7.08 & 5.68 & $5.55 \mathrm{a}$ & 112.50 & $114.48 \mathrm{~b}$ \\
\hline & spraying & Without & 7.10 & 6.88 & 5.38 & $5.30 \mathrm{~d}$ & 104.98 & $108.25 \mathrm{c}$ \\
\hline & Without & Inoculation & 7.50 & 7.48 & 5.58 & $5.53 \mathrm{ab}$ & 120.35 & $121.18 \mathrm{a}$ \\
\hline & Willioul & Without & 7.45 & 7.10 & 5.28 & $5.40 \mathrm{c}$ & 96.50 & $95.33 \mathrm{~d}$ \\
\hline \multirow{4}{*}{0} & Snraving & Inoculation & 6.78 & 6.58 & 5.23 & $5.30 \mathrm{~d}$ & 92.90 & $87.13 \mathrm{f}$ \\
\hline & spraying & Without & 6.25 & 7.18 & 5.08 & $5.18 \mathrm{e}$ & 85.55 & $91.93 \mathrm{e}$ \\
\hline & Without & Inoculation & 7.10 & 6.38 & 5.20 & $5.30 \mathrm{~d}$ & 81.20 & $86.18 \mathrm{f}$ \\
\hline & Willioul & Without & 6.68 & 6.28 & 4.93 & $5.13 \mathrm{e}$ & 73.88 & $74.40 \mathrm{~g}$ \\
\hline \multirow{4}{*}{15} & Spraving & Inoculation & 7.25 & 7.20 & 5.65 & $5.53 \mathrm{ab}$ & 108.90 & $118.48 \mathrm{a}$ \\
\hline & Spraying & Without & 7.00 & 6.88 & 5.43 & $5.43 \mathrm{bc}$ & 107.18 & $114.23 \mathrm{~b}$ \\
\hline & Without & Inoculation & 7.23 & 7.18 & 5.50 & $5.35 \mathrm{~cd}$ & 89.33 & $91.68 \mathrm{e}$ \\
\hline & Witnoul & Without & 7.05 & 6.48 & 5.23 & $5.50 \mathrm{ab}$ & 96.83 & $98.43 \mathrm{~d}$ \\
\hline F-test & & & NS & NS & NS & $* *$ & NS & $* *$ \\
\hline
\end{tabular}

**, * and NS indicate significant differences at $\mathrm{P}<0.01,<0.05$ and not significant, respectively according to $\mathrm{F}$-test.

In the same column, means followed by the same letter are not significantly different at $5 \%$ level according to Duncan's test.

No significant differences in fruit length, fruit diameter and average fruit weight except average fruit weight in the second season, due to the interaction between phosphorus levels at $15 \mathrm{~kg} \mathrm{P}_{2} \mathrm{O}_{5}$ and salicylic spraying. The interaction between phosphorus levels and biofertilizer inoculation significantly affected fruit length in the second season, fruit diameter in the second season and average fruit weight in both seasons. The highest average in the second season and average fruit weight in both seasons. 
The highest average fruit weight $(116,43$ and 117.83) $\mathrm{g}$ /fruit were obtained with $30 \mathrm{~kg} \mathrm{P}_{2} \mathrm{O}_{5}+$ biofertilizer inoculation. Average fruit weight and fruit diameter in the second season, were significantly affected by the interaction between salicylic spraying and biofertilizer inoculation. The interaction between phosphorus levels, salicylic spraying and biofertilizer inoculation significantly affected average fruit weight in the second season only. The highest value was obtained with $15 \mathrm{~kg} \mathrm{P}_{2} \mathrm{O}_{5}+$ salicylic spraying + biofertilizer inoculation.

Effect of phosphorus levels, spraying with salicylic and biofertilizer inoculation on tomato TSS \%, vitamin C $\mathrm{mg} / 100 \mathrm{~g}$ fresh weight and acidity $\%$ are presented in Table
(6). Phosphorus levels high significantly affected $\mathrm{TSS} \%$, vitamin $\mathrm{C}$ and acidity $\%$ in both seasons. The highest values $(5.36,5.38)$ of TSS, $(0.31,0.33)$ of acidity were obtained with $30 \mathrm{~kg} \mathrm{P}_{2} \mathrm{O}_{5} \mathrm{fed}^{-1}$, while the highest values of vitamin $\mathrm{C}(28.95,27.37) \mathrm{mg} / 100 \mathrm{~g}$ fresh weight were obtained with $15 \mathrm{~kg} \mathrm{P}_{2} \mathrm{O}_{5}$ fed $^{-1}$. These results are in line with those obtained by Khan . (2009).

Inoculation with phosphate solubilizing bacteria high significantly increased tomato $\mathrm{TSS} \%(4.94,5.18)$, vitamin C $(27.12,26.84)$ and acidity \% $(0.31,0.33)$ comparing with the control, in the first and second seasons, respectively. The obtained results are in agreement with those obtained by Sreedevi Sarsan (2016).

Table 6. Effect of salicylic acid foliar spraying, phosphorus fertilization and inoculation with solubilizing phosphate bacteria and their interaction on fruit chemical quality of tomato during the two growing seasons of 2014-2015.

\begin{tabular}{|c|c|c|c|c|c|c|c|c|}
\hline \multicolumn{3}{|c|}{ Treatments } & \multicolumn{2}{|c|}{ TSS (\%) } & \multicolumn{2}{|c|}{ Vitamin C (mg/100 fresh weight) } & \multicolumn{2}{|c|}{ Acidity (\%) } \\
\hline $\begin{array}{l}\text { Phosphorus } \\
\text { levels (kg/fed.) }\end{array}$ & $\begin{array}{l}\text { Salicylic acid } \\
\text { spraying }\end{array}$ & $\begin{array}{c}\text { Inoculation } \\
\text { bacteria }\end{array}$ & $\begin{array}{c}\text { First } \\
\text { season }\end{array}$ & $\begin{array}{l}\text { Second } \\
\text { season }\end{array}$ & $\begin{array}{l}\text { First } \\
\text { season }\end{array}$ & $\begin{array}{r}\text { Second } \\
\text { season }\end{array}$ & $\begin{array}{l}\text { First } \\
\text { season }\end{array}$ & $\begin{array}{l}\text { Second } \\
\text { season }\end{array}$ \\
\hline 30 & & & $5.36 \mathrm{a}$ & $5.38 \mathrm{a}$ & $23.00 \mathrm{c}$ & $25.05 \mathrm{~b}$ & $0.310 \mathrm{a}$ & $0.326 \mathrm{a}$ \\
\hline 0 & & & $4.10 \mathrm{c}$ & $4.49 \mathrm{~b}$ & $26.23 \mathrm{~b}$ & $25.08 \mathrm{~b}$ & $0.266 \mathrm{c}$ & $0.303 \mathrm{c}$ \\
\hline 15 & & & $4.75 \mathrm{~b}$ & $5.35 \mathrm{a}$ & $28.95 \mathrm{a}$ & $27.37 \mathrm{a}$ & $0.294 \mathrm{~b}$ & $0.314 \mathrm{~b}$ \\
\hline F-test & & & $* *$ & $* *$ & $* *$ & $* *$ & $* *$ & $* *$ \\
\hline & Spraying & & $4.87 \mathrm{a}$ & 5.11 & $29.23 \mathrm{a}$ & $27.14 \mathrm{a}$ & $0.307 \mathrm{a}$ & $0.317 \mathrm{a}$ \\
\hline & Without & & $4.60 \mathrm{~b}$ & 5.04 & $22.89 \mathrm{~b}$ & $24.52 \mathrm{~b}$ & $0.273 \mathrm{~b}$ & $0.310 \mathrm{~b}$ \\
\hline F-test & & & $* *$ & $\mathrm{NS}$ & $* *$ & $* *$ & $* *$ & $*$ \\
\hline & & Inoculation & $4.94 \mathrm{a}$ & $5.18 \mathrm{a}$ & $27.12 \mathrm{a}$ & $26.84 \mathrm{a}$ & $0.314 \mathrm{a}$ & $0.333 \mathrm{a}$ \\
\hline & & Without & $4.53 \mathrm{~b}$ & $4.97 \mathrm{a}$ & $25.01 \mathrm{~b}$ & $24.82 \mathrm{~b}$ & $0.266 \mathrm{~b}$ & $0.294 \mathrm{~b}$ \\
\hline F-test & & & $* *$ & $* *$ & $* *$ & $* *$ & $* *$ & $* *$ \\
\hline & Spraying & & 5.52 & $5.52 \mathrm{a}$ & $23.72 \mathrm{c}$ & $25.73 b$ & $0.325 \mathrm{a}$ & 0.331 \\
\hline 30 & Without & & 5.20 & $5.25 \mathrm{a}$ & $22.28 \mathrm{~d}$ & $24.37 \mathrm{c}$ & 0.294 bc & 0.321 \\
\hline & Spraying & & 4.17 & $4.55 \mathrm{~b}$ & $30.12 \mathrm{~b}$ & 26.55 & $0.286 \mathrm{bc}$ & 0.307 \\
\hline 0 & Without & & 4.03 & $4.43 \mathrm{~b}$ & $22.35 \mathrm{~d}$ & $23.60 \mathrm{c}$ & $0.245 \mathrm{~b}$ & 0.296 \\
\hline 15 & Spraying & & 4.93 & $5.25 \mathrm{a}$ & $33.85 \mathrm{a}$ & $29.13 \mathrm{a}$ & $0.309 \mathrm{ab}$ & 0.313 \\
\hline 15 & Without & & 4.57 & $5.45 \mathrm{a}$ & $24.05 \mathrm{c}$ & $25.60 \mathrm{~b}$ & $0.279 \mathrm{c}$ & 0.315 \\
\hline F-test & & & NS & $* *$ & $* *$ & $* *$ & $* *$ & NS \\
\hline & & Inoculation & $5.67 \mathrm{a}$ & 5.60 & $23.63 \mathrm{~d}$ & $26.42 \mathrm{~b}$ & $0.331 \mathrm{a}$ & $0.348 \mathrm{a}$ \\
\hline 30 & & Without & $4.05 \mathrm{~b}$ & 5.17 & $22.37 \mathrm{e}$ & $23.68 \mathrm{e}$ & $0.289 \mathrm{~b}$ & $0.303 \mathrm{~d}$ \\
\hline 0 & & Inoculation & $4.30 \mathrm{e}$ & 4.63 & $25.22 \mathrm{c}$ & $25.12 \mathrm{~d}$ & $0.289 \mathrm{~b}$ & $0.313 \mathrm{c}$ \\
\hline 0 & & Without & $3.90 \mathrm{f}$ & 4.35 & $27.25 b$ & $25.03 \mathrm{~d}$ & $0.242 \mathrm{~d}$ & $0.291 \mathrm{e}$ \\
\hline & & Inoculation & $4.85 \mathrm{c}$ & 5.30 & $32.50 \mathrm{a}$ & $28.98 \mathrm{a}$ & $0.323 \mathrm{a}$ & $0.338 \mathrm{~b}$ \\
\hline 15 & & Without & $4.65 \mathrm{~d}$ & 5.40 & $25.40 \mathrm{c}$ & $25.75 \mathrm{c}$ & $0.265 \mathrm{c}$ & $0.289 \mathrm{e}$ \\
\hline F-test & & & $*$ & NS & $* *$ & $* *$ & $* *$ & $* *$ \\
\hline & & Inoculation & 5.06 & $5.26 \mathrm{a}$ & $29.49 \mathrm{a}$ & $27.62 \mathrm{a}$ & $0.317 \mathrm{a}$ & 0.335 \\
\hline & Spraying & Without & 5.69 & $4.96 \mathrm{~b}$ & $28.97 \mathrm{a}$ & $26.67 \mathrm{~b}$ & $0.297 \mathrm{c}$ & 0.299 \\
\hline & & Inoculation & 4.82 & $5.10 \mathrm{ab}$ & $24.74 \mathrm{~b}$ & $26.06 \mathrm{~b}$ & $0.311 \mathrm{~b}$ & 0.330 \\
\hline & Without & Without & 4.38 & $4.99 \mathrm{~b}$ & $21.04 \mathrm{c}$ & $22.99 \mathrm{c}$ & $0.234 \mathrm{~d}$ & 0.290 \\
\hline F-test & & & NS & $* *$ & $* *$ & $* *$ & $* *$ & NS \\
\hline & & Inoculation & 5.83 & 5.80 & $23.63 \mathrm{e}$ & $26.87 \mathrm{c}$ & $0.336 \mathrm{a}$ & $0.347 \mathrm{a}$ \\
\hline 30 & Sprayıng & Without & 5.20 & 5.23 & $23.80 \mathrm{e}$ & $24.60 \mathrm{e}$ & $0.314 \mathrm{c}$ & $0.315 \mathrm{~d}$ \\
\hline 30 & & Inoculation & 5.50 & 5.40 & $23.63 \mathrm{e}$ & $25.97 \mathrm{~d}$ & $0.325 \mathrm{~b}$ & $0.349 \mathrm{a}$ \\
\hline & Without & Without & 4.90 & 5.10 & $20.93 \mathrm{f}$ & $22.77 \mathrm{f}$ & $0.264 \mathrm{~g}$ & $0.292 \mathrm{f}$ \\
\hline & & Inoculation & 4.33 & 4.57 & $26.67 \mathrm{a}$ & $25.77 \mathrm{~d}$ & $0.292 \mathrm{~d}$ & $0.322 \mathrm{c}$ \\
\hline & Spraying & Without & 4.00 & 4.53 & $33.57 \mathrm{~b}$ & $27.33 \mathrm{bc}$ & $0.281 \mathrm{f}$ & $0.292 \mathrm{f}$ \\
\hline 0 & & Inoculation & 4.27 & 4.70 & $23.77 \mathrm{e}$ & $24.47 \mathrm{e}$ & $0.286 \mathrm{e}$ & $0.303 \mathrm{e}$ \\
\hline & Without & Without & 3.80 & 4.17 & $20.93 \mathrm{f}$ & $22.73 \mathrm{f}$ & $0.203 \mathrm{i}$ & $0.289 \mathrm{f}$ \\
\hline & & Inoculation & 5.00 & 5.40 & $38.17 \mathrm{a}$ & $30.23 \mathrm{a}$ & $0.323 \mathrm{~b}$ & $0.337 \mathrm{~b}$ \\
\hline 15 & Spraying & Without & 4.87 & 5.10 & $29.53 \mathrm{c}$ & $28.08 \mathrm{~b}$ & $0.296 \mathrm{~d}$ & $0.289 \mathrm{f}$ \\
\hline 15 & & Inoculation & 4.70 & 5.20 & $26.83 \mathrm{~d}$ & $27.73 \mathrm{~b}$ & $0.323 \mathrm{~b}$ & $0.339 \mathrm{~b}$ \\
\hline & Without & Without & 4.43 & 5.70 & $21.27 \mathrm{f}$ & $23.47 \mathrm{f}$ & $0.235 \mathrm{~h}$ & $0.290 \mathrm{f}$ \\
\hline F-test & & & NS & NS & $* *$ & $* *$ & $* *$ & $* *$ \\
\hline
\end{tabular}

**, * and NS indicate significant differences at $\mathrm{P}<0.01,<0.05$ and not significant, respectively according to $\mathrm{F}$-test.

In the same column, means followed by the same letter are not significantly different at $5 \%$ level according to Duncan's test. 
The interaction between phosphorus levels and salicylic spraying significantly affect TSS\% in the second season, the best value $(5.45 \%)$, vitamin $\mathrm{C}$ in both seasons $(33.85,29.13)$ were obtained with $15 \mathrm{~kg} \mathrm{P}_{2} \mathrm{O}_{5} \mathrm{fed}^{-1}+$ spraying with salicylic.

The interaction between phosphorus levels and biofertilizer inoculation (Table 6) show that $15 \mathrm{~kg} \mathrm{P}_{2} \mathrm{O}_{5}$ $\mathrm{fed}^{-1}+$ biofertilizer inoculation had the highest vitamin $\mathrm{C}$, while the highest acidity in both seasons and TSS in the first season were observed with $30 \mathrm{~kg} \mathrm{P}_{2} \mathrm{O}_{5} \mathrm{fed}^{-1}+$ biofertilizer inoculation. The interaction between salicylic spraying and bioinoculation had the highest values of TSS, vitamin $\mathrm{C}$ and acidity. The interaction between $\mathrm{P}$ levels, salicylic spraying and bio-inoculation show that the best vitamin $\mathrm{C}$, values with $15 \mathrm{~kg} \mathrm{P}_{2} \mathrm{O}_{5} \mathrm{fed}^{-1}+$ salicylic spraying + biofertilizer inoculation, while the highest acidity values with $30 \mathrm{~kg} \mathrm{P}_{2} \mathrm{O}_{5} \mathrm{fed}^{-1}+$ salicylic spraying + bioinoculation.

Data in Table (7) show that, phosphorus fertilization levels high significantly affected $\mathrm{N} \%$, and $\mathrm{K} \%$ in tomato shoot and fruits. The highest values $(0.64$ and $0.68) \mathrm{N}$ in shoot, $(0.92$ and 0.90$) \mathrm{N}$ in fruits in the first and second season, respectively. The highest values of $\mathrm{K} \%$ (0.91 and 0.89) in the shoot and (2.86 and 2.68) in the fruits in the first and second season, respectively were obtained with $30 \mathrm{~kg} \mathrm{P}_{2} \mathrm{O}_{5}$ fed $^{-1}$. On the other hand, the lowest values were detected without phosphorus treatment. These results are in agreement with those obtained by Kamil . (2015).

Table 7. Effect of salicylic acid foliar spraying, phosphorus fertilization and inoculation with solubilizing phosphate bacteria and their interaction on $\mathrm{N}$ and $\mathrm{K} \%$ in tomato shoot and fruits during the two growing seasons of 2014-2015.

\begin{tabular}{|c|c|c|c|c|c|c|c|c|c|c|}
\hline \multirow{3}{*}{$\begin{array}{l} \\
\text { Phosphorus } \\
\text { levels } \\
\text { (kg/fed.) }\end{array}$} & \multicolumn{2}{|c|}{ Treatments } & \multicolumn{4}{|c|}{ N\% } & \multicolumn{4}{|c|}{ K\% } \\
\hline & \multirow{2}{*}{$\begin{array}{l}\text { Salicylic } \\
\text { acid } \\
\text { spraying }\end{array}$} & \multirow[b]{2}{*}{$\begin{array}{c}\text { Inoculation } \\
\text { bacteria }\end{array}$} & \multicolumn{2}{|c|}{ In shoot } & \multicolumn{2}{|c|}{ In fruits } & \multicolumn{2}{|c|}{ In shoot } & \multicolumn{2}{|c|}{ In fruits } \\
\hline & & & $\begin{array}{c}\text { First } \\
\text { season }\end{array}$ & $\begin{array}{l}\text { Second } \\
\text { season }\end{array}$ & $\begin{array}{c}\text { First } \\
\text { season }\end{array}$ & $\begin{array}{l}\text { Second } \\
\text { season }\end{array}$ & $\begin{array}{c}\text { First } \\
\text { season }\end{array}$ & $\begin{array}{l}\text { Second } \\
\text { season }\end{array}$ & $\begin{array}{c}\text { First } \\
\text { season }\end{array}$ & $\begin{array}{l}\text { Second } \\
\text { season }\end{array}$ \\
\hline 30 & & & $0.638 \mathrm{a}$ & $0.683 \mathrm{a}$ & $0.927 \mathrm{a}$ & 0.903 & $0.908 \mathrm{a}$ & $0.892 \mathrm{a}$ & $2.865 \mathrm{a}$ & $2.681 \mathrm{a}$ \\
\hline 0 & & & $0.495 \mathrm{c}$ & $0.563 \mathrm{~b}$ & $0.777 \mathrm{c}$ & 0.861 & $0.819 \mathrm{c}$ & $0.827 \mathrm{~b}$ & $2.142 \mathrm{c}$ & $2.416 b$ \\
\hline 15 & & & $0.543 \mathrm{~b}$ & $0.608 \mathrm{~b}$ & $0.831 \mathrm{~b}$ & 0.889 & $0.883 \mathrm{~b}$ & $0.867 \mathrm{a}$ & $2.635 \mathrm{~b}$ & $2.536 \mathrm{ab}$ \\
\hline F-test & & & $* *$ & $* *$ & $* *$ & NS & ** & $* *$ & ** & * \\
\hline & Spraying & & 0.556 & 0.613 & $0.851 \mathrm{a}$ & 0.893 & 0.872 & 0.863 & $2.616 \mathrm{a}$ & $2.618 \mathrm{a}$ \\
\hline & Without & & 0.561 & 0.623 & $0.839 \mathrm{~b}$ & 0.876 & 0.869 & 0.861 & $2.479 \mathrm{~b}$ & $2.471 \mathrm{~b}$ \\
\hline F-test & & & NS & NS & * & NS & NS & NS & $* *$ & ** \\
\hline & & Inoculation & $0.582 \mathrm{a}$ & $0.644 \mathrm{a}$ & $0.873 \mathrm{a}$ & $0.913 \mathrm{a}$ & $0.899 \mathrm{a}$ & $0.873 \mathrm{a}$ & $2.756 \mathrm{a}$ & $2.675 \mathrm{a}$ \\
\hline & & Wit & $0.535 \mathrm{~b}$ & $0.592 \mathrm{~b}$ & $0.818 \mathrm{~b}$ & $0.856 \mathrm{~b}$ & $0.842 \mathrm{~b}$ & $0.851 \mathrm{~b}$ & $2.339 \mathrm{~b}$ & $2.413 \mathrm{~b}$ \\
\hline F-test & & & ** & ** & ** & ** & ** & * & $* *$ & ** \\
\hline \multirow{2}{*}{30} & Spraying & & 0.632 & $0.652 \mathrm{~b}$ & $0.925 \mathrm{a}$ & 0.897 & 0.900 & $0.890 \mathrm{a}$ & $3.042 \mathrm{a}$ & 2.793 \\
\hline & Without & & 0.643 & $0.715 \mathrm{a}$ & $0.930 \mathrm{a}$ & 0.910 & 0.917 & $0.893 \mathrm{a}$ & $2.688 \mathrm{~b}$ & 2.568 \\
\hline \multirow{2}{*}{0} & Spraying & & 0.502 & $0.575 \mathrm{~d}$ & $0.783 \mathrm{~b}$ & 0.882 & 0.825 & $0.820 \mathrm{c}$ & $2.130 \mathrm{~d}$ & 2.438 \\
\hline & Without & & 0.488 & $0.550 \mathrm{~d}$ & $0.772 \mathrm{~b}$ & 0.840 & 0.813 & $0.833 \mathrm{c}$ & $2.155 \mathrm{~d}$ & 2.393 \\
\hline \multirow{2}{*}{15} & Spraying & & 0.535 & $0.605 \mathrm{c}$ & $0.845 \mathrm{~b}$ & 0.900 & 0.877 & $0.898 \mathrm{a}$ & $2.675 \mathrm{~b}$ & 2.628 \\
\hline & Without & & 0.552 & $0.612 \mathrm{c}$ & $0.817 \mathrm{c}$ & 0.878 & 0.890 & $0.855 \mathrm{~b}$ & $2.595 \mathrm{c}$ & 2.450 \\
\hline F-test & & & NS & $* *$ & * & NS & NS & * & ** & NS \\
\hline \multirow{2}{*}{30} & & Inoct & $0.668 \mathrm{a}$ & 0.707 & $0.960 \mathrm{a}$ & $0.943 \mathrm{a}$ & $0.937 \mathrm{a}$ & 0.902 & $3.110 \mathrm{a}$ & $2.870 \mathrm{a}$ \\
\hline & & Without & $0.607 \mathrm{~b}$ & 0.660 & $0.895 \mathrm{~b}$ & $0.863 \mathrm{e}$ & $0.880 \mathrm{c}$ & 0.882 & $2.260 \mathrm{c}$ & $2.492 \mathrm{c}$ \\
\hline \multirow{2}{*}{0} & & Inoculation & $0.508 \mathrm{e}$ & 0.598 & $0.795 \mathrm{~d}$ & $0.888 \mathrm{c}$ & $0.843 \mathrm{e}$ & 0.840 & $2.188 \mathrm{e}$ & $2.467 \mathrm{c}$ \\
\hline & & Without & $0.482 \mathrm{f}$ & 0.527 & $0.760 \mathrm{e}$ & $0.833 \mathrm{f}$ & $0.795 \mathrm{f}$ & 0.813 & $2.097 \mathrm{f}$ & $23.365 \mathrm{c}$ \\
\hline \multirow{2}{*}{15} & & Inoculation & $0.570 \mathrm{c}$ & 0.627 & $0.863 \mathrm{c}$ & $0.908 \mathrm{~b}$ & $0.917 \mathrm{~b}$ & 0.877 & $2.970 \mathrm{~b}$ & $2.688 \mathrm{~b}$ \\
\hline & & Without & $0.517 \mathrm{~d}$ & 0.590 & $0.798 \mathrm{~d}$ & $0.870 \mathrm{~d}$ & $0.850 \mathrm{~d}$ & 0.857 & $2.300 \mathrm{~d}$ & $2.383 \mathrm{c}$ \\
\hline \multirow[t]{6}{*}{ F-test } & & & $* *$ & NS & ** & $* *$ & * & NS & ** & * \\
\hline & $\mathrm{S}_{t_{2}}$ & Inoct & $0.572 \mathrm{~b}$ & 0.637 & $0.884 \mathrm{a}$ & $0.934 \mathrm{a}$ & $0.907 \mathrm{a}$ & 0.876 & $2.796 \mathrm{a}$ & 2.789 \\
\hline & Spr & Without & $0.540 \mathrm{c}$ & 0.589 & $0.818 \mathrm{c}$ & $0.851 \mathrm{~d}$ & $0.837 \mathrm{~d}$ & 0.850 & $2.436 \mathrm{c}$ & 2.447 \\
\hline & & Inoculation & $0.592 \mathrm{a}$ & 0.651 & $0.861 \mathrm{~b}$ & $0.892 \mathrm{~b}$ & $0.891 \mathrm{~b}$ & 0.870 & $2.717 \mathrm{~b}$ & 2.561 \\
\hline & & Without & $0.520 \mathrm{~d}$ & 0.596 & $0.818 \mathrm{c}$ & $0.860 \mathrm{c}$ & $0.847 \mathrm{c}$ & 0.851 & $2.242 \mathrm{~d}$ & 2.380 \\
\hline & & & $* *$ & NS & $* *$ & ** & $* *$ & NS & $* *$ & NS \\
\hline \multirow{4}{*}{30} & & Inoculation & $0.647 \mathrm{~b}$ & $0.660 \mathrm{bc}$ & $0.970 \mathrm{a}$ & 0.953 & $0.940 \mathrm{a}$ & 0.899 & 3.243 & 3.017 \\
\hline & ing & Without & $0.617 \mathrm{c}$ & $0.643 \mathrm{bcd}$ & $0.880 \mathrm{~d}$ & 0.840 & $0.960 \mathrm{~d}$ & 0.883 & 2.840 & 2.570 \\
\hline & $\mathrm{y}$ & Inoculation & $0.690 \mathrm{a}$ & $0.753 \mathrm{a}$ & $0.950 \mathrm{~b}$ & 0.933 & $0.933 \mathrm{~b}$ & 0.907 & 2.977 & 2.723 \\
\hline & Without & & $0.597 \mathrm{~d}$ & $0.677 \mathrm{~b}$ & $0.910 \mathrm{c}$ & 0.887 & $0.900 \mathrm{c}$ & 0.880 & 2.400 & 2.413 \\
\hline \multirow{4}{*}{0} & & Inoculation & $0.520 \mathrm{~g}$ & $0.623 \mathrm{de}$ & $0.810 \mathrm{f}$ & 0.927 & $0.850 \mathrm{e}$ & 0.840 & 2.143 & 2.490 \\
\hline & $\mathrm{S}$ & Withol & $0.483 \mathrm{j}$ & $0.527 \mathrm{~g}$ & $0.757 \mathrm{~h}$ & 0.837 & $0.800 \mathrm{~g}$ & 0.800 & 2.117 & 2.387 \\
\hline & 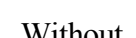 & Inoculation & $0.647 \mathrm{~b}$ & $0.573 \mathrm{f}$ & $0.780 \mathrm{~g}$ & 0.850 & $0.837 \mathrm{f}$ & 0.840 & 2.233 & 2.490 \\
\hline & Withoul & Wit & $0.617 \mathrm{c}$ & $0.527 \mathrm{~g}$ & $0.763 \mathrm{~h}$ & 0.830 & $0.790 \mathrm{~h}$ & 0.827 & 2.077 & 2.387 \\
\hline \multirow{5}{*}{15} & & Inoculation & $0.550 \mathrm{f}$ & 0.627 cde & $0.873 \mathrm{~d}$ & 0.923 & $0.930 \mathrm{~b}$ & 0.890 & 3.000 & 2.860 \\
\hline & Spraying & Withol & $0.520 \mathrm{~g}$ & 0.597 ef & $0.817 \mathrm{f}$ & 0.847 & $0.850 \mathrm{e}$ & 0.867 & 2.350 & 2.383 \\
\hline & & Inoculation & $0.590 \mathrm{e}$ & 0.627 cde & $0.853 \mathrm{e}$ & 0.893 & $0.903 \mathrm{c}$ & 0.863 & 2.940 & 2.517 \\
\hline & & Without & $0.513 \mathrm{~h}$ & $0.583 \mathrm{f}$ & $0.780 \mathrm{~g}$ & 0.863 & $0.850 \mathrm{e}$ & 0.847 & 2.250 & 2.383 \\
\hline & est & & & $* *$ & & NS & & NS & NS & NS \\
\hline
\end{tabular}

**, * and NS indicate significant differences at $\mathrm{P}<0.01,<0.05$ and not significant, respectively according to $\mathrm{F}$-test.

In the same column, means followed by the same letter are not significantly different at $5 \%$ level according to Duncan's test. 
Salicylic spraying high significantly increased $\mathrm{K} \%$ in fruits in both seasons (2.62 and 2.62) compared with (2.48 and 2.47). On the other hand, no significant differences were detected in $\mathrm{N} \%$ of shoot, fruits and $\mathrm{K} \%$ of shoot.

In respect of phosphorus solubilizing bacteria inoculation. Inoculation high significantly increased $\mathrm{N} \%$ and $\mathrm{K} \%$ in tomato shoot and fruits in both seasons. These results are in harmony with those obtained by Turan . (2007) and Nanis . (2018). The interaction between phosphorus levels and biofertilizer inoculation significantly affected $\mathrm{N} \%$ and $\mathrm{K} \%$ of shoot and fruits. The highest values were recorded with $30 \mathrm{~kg} \mathrm{P}_{2} \mathrm{O}_{5} \mathrm{fed}^{-1}+$ phosphorus solubilizing bacteria inoculation. The interaction between salicylic spraying and bacteria inoculation high significantly affected $\mathrm{N} \%$ in fruits in both seasons and $\mathrm{K} \%$ in shoot and fruit in the first season only. The highest values were observed with (salicylic spraying + phosphate solubilizing bacteria inoculation).
The interaction between phosphorus levels, salicylic spraying and biofertilizer inoculation significantly affected $\mathrm{N} \%$ in shoot, $\mathrm{N} \%$ in fruit in the first season only, $\mathrm{K} \%$ in shoot in the first season only. The highest $\mathrm{N} \%$ in shoot $(0.69,0.75)$ were obtained with $\left(30 \mathrm{~kg} \mathrm{P}_{2} \mathrm{O}_{5} \mathrm{fed}^{-1}+\right.$ without salicylic spraying + biofertilizer inoculation) treatment. The highest $\mathrm{N} \%$ in fruits (0.97) was observed with $\left(30 \mathrm{~kg} \mathrm{P}_{2} \mathrm{O}_{5}\right.$ fed $^{-1}+$ salicylic spraying + biofertilizer inoculation) treatment. Potassium $\%$ in the shoot had the same sequence.

Effect of phosphorus fertilization levels and salicylic spraying and phosphate solubilizing bacteria inoculation on curly top virus (TCTV) of tomato plants are shown in Table (8).

From the tabulated data clear that, $15 \mathrm{~kg} \mathrm{P}_{2} \mathrm{O}_{5}$ fed $^{-1}$ had the lowest disease incidence \% values (26.27 and $24.04 \%$ ) in the first and second season, respectively. It had the highest reduction infection \% values (49.0 and 48.39\%) in the first and second season, respectively.

Table 8. Effect of salicylic acid foliar spraying, phosphorus levels and inoculation with solubilizing bacteria on disease severity and incidence of tomato curly top virus (TCTV).

\begin{tabular}{|c|c|c|c|c|c|c|c|c|}
\hline & \multicolumn{2}{|l|}{ Treatments } & \multicolumn{2}{|c|}{ Disease incidence \% } & \multicolumn{2}{|c|}{ Reduction infection \% } & \multicolumn{2}{|c|}{ Disease severity \% } \\
\hline $\begin{array}{l}\text { Phosphorus } \\
\text { levels (kg/fed.) }\end{array}$ & $\begin{array}{c}\text { Salicylic acid } \\
\text { spraying }\end{array}$ & $\begin{array}{c}\text { Inoculation } \\
\text { bacteria }\end{array}$ & $\begin{array}{c}\text { First } \\
\text { season }\end{array}$ & $\begin{array}{c}\text { Second } \\
\text { season }\end{array}$ & $\begin{array}{c}\text { First } \\
\text { season }\end{array}$ & $\begin{array}{c}\text { Second } \\
\text { season }\end{array}$ & $\begin{array}{c}\text { First } \\
\text { season }\end{array}$ & $\begin{array}{c}\text { Second } \\
\text { season }\end{array}$ \\
\hline$\overline{0}$ & & & 29.3 & 33.90 & 38.49 & 27.97 & 13.83 & 19.95 \\
\hline 15 & & & 26.27 & 24.04 & 49.00 & 48.39 & 12.21 & 12.23 \\
\hline 30 & & & 28.16 & 29.10 & 40.93 & 39.04 & 13.30 & 19.21 \\
\hline & Spraying & & 18.02 & 18.42 & 62.02 & 60.02 & 4.43 & 9.75 \\
\hline & Without & & 37.79 & 39.58 & 23.59 & 16.04 & 21.79 & 25.17 \\
\hline & Spraying & Inoculation & 18.61 & 18.42 & 60.40 & 61.22 & 2.66 & 6.38 \\
\hline 0 & Without & Without & 37.70 & 39.70 & 21.45 & 16.85 & 23.93 & 34.04 \\
\hline & Spraying & Inoculation & 22.63 & 25.78 & 53.10 & 45.72 & 8.51 & 17.55 \\
\hline 15 & Without & Without & 35.97 & 42.02 & 23.87 & 10.21 & 19.14 & 22.34 \\
\hline & Spraying & Inoculation & 12.83 & 11.05 & 72.55 & 75.72 & 2.12 & 5.31 \\
\hline 30 & Without & Without & 39.70 & 37.03 & 25.44 & 21.05 & 22.30 & 19.14 \\
\hline
\end{tabular}

Also, it had the lowest disease severity\% values (12.21 and 12.23\%) comparing with the other used phosphorus levels. On the other hand, treatment of without phosphorus had the highest disease incidence \% (29.3 and 33.9), lowest reduction infection \% (38.49 and $27.97 \%$ ) and highest disease severity $\%$. In respect to disease severity comparing with the used rating scale (04) all the values of phosphorus levels $(0,15$ and $30 \mathrm{~kg}$ $\mathrm{P}_{2} \mathrm{O}_{5} \mathrm{fed}^{-1}$ ) from 12.21 up to $19.95 \%$ lies in class one (11-20\%), this means that effect of phosphorus levels was less effect on tomato curly top virus (TCTV). These results are in same line with those obtained by Klopper . (2004); Rashid . (1995); Keinath and Loria (1996); Choudhary . (2007); Lanlcioni (2008); El-Borollosy and oraby (2012); Huber and Graham (1999) and Huber . (2012).

In respect to salicylic spraying, it was decreased disease incidence \% from (37.79 and 39.58) to (18.02 and 18.42), increased reduction infection \% from (23.59 and 16.04) to (62.02 and 60.02) and decreased disease severity \% from (21.79 and 25.17$)$ to (4.43 and 9.75) in the first and second season, respectively.

Comparing the disease severity values under salicylic spraying (with and without) with the used rating scale clear that the values with salicylic spraying (4.43 and $9.75 \%$ ) lies in the class zero ( $0 \%$ to $10 \%)$, while the values of without salicylic spraying $(21.79$ and $25.17 \%)$ lies in the class $2(21-30 \%)$. This means that salicylic spraying was effective in decreasing tomato curly top virus (TCTV). These results are harmony with those obtained by Shah and Klessig (1999); Kobeasy and Salwa El-Hamid (2005); Radwan . (2007); Radwan . (2008); Hayat . (2010), Aminalah . (2011) and Blaebler . (2011) who concluded that salicylic is an important signal molecule in plant that is an important signal molecule in plant that is required for the induction systemic acquired resistance against wide variety of pathogens including virus.

The interaction between phosphorus levels and salicylic spraying and bioinoculation show that the best treatment was $15 \mathrm{~kg} \mathrm{P}_{2} \mathrm{O}_{5}$ fed $^{-1}+$ salicylic spraying + bioinoculation in both seasons.

\section{CONCLUSION}

Under non-saline soil ECe $2.1 \mathrm{dSm}^{-1}$, moderate available phosphorus (5-6 ppm) $15 \mathrm{~kg} \mathrm{P}_{2} \mathrm{O}_{5} \mathrm{fed}^{-1}+$ inoculation with phosphate solubilizing bacteria produced tomato best growth parameters, yield, yield components and quality. Spraying with salicylic at the rate $300 \mathrm{ppm}$ in the spraying solution induced resistance against curly top virus (TCTV) and decreased disease severity $\%$. 


\section{REFERENCES}

Aminalah, T.; Z. Maryam; T. Asma; D. Akbar and K.H. Mina (2011). Role of salicylic acid in resistance to plant viruses. Genetics in the $3^{\text {rd }}$ Millennium, 8, 2203-2212.

A.O.A.C. (1990). Official Methods of Analysis, Association of Official Analytical Chemists, $15^{\text {th }}$ ed. Washington D.C., USA.

Baebler, S.; K. Stare; M. Kovac; A. Blejec; N. Prezelj; T. Stare . (2011). Dynamics of responses in compatible potato virus $\mathrm{Y}$ interaction are modulated by salicylic acid. PLoS ONE, 6(12), e29009. Doi:10.1371/journal.pone.0029009.

Black, C.A.; D. Evans; L.E. Ensminger; L. White; F.E. Clark and R.C. Dinauer (1965). Methods of Soil Analysis. Sponsored Jointly by the American Soc. Of Agron. And American Soc. For Testing and Materials. Soc. of Agron. Inc. USA.

Choudhary, D.K.; A. Prakash and B.N. Johri (2007). Induced systemic resistance (ISR) in plants: mechanism of action. Indian Journal of Microbiology, 47(4): 289-297.

Cottenie, A.; M. Veloo; L. Kiekens; G. Velghe and R. Camerlynck (1982). Chemical analysis of plants and soils. Laboratory of Analytical and Agrochemistry State Univ. Ghent-Belgium.

Dangl, J.L. and J.D.g. Jones (2001). Plant pathogens and integrated defence responses to infection. Nature, 411: 826-833.

Danpsey, D.A.; J. Shah and D.F. Klessig (1999). Salicylic acid diseases resistance in plant. Crit. Rev. Plant Sci. 18: 547-575.

Deepika Divya Kadiri; Naresh Gorle; Krishmakanth Varada Raju Peetala and Sujatha Peela (2013). Isolation, screening and identification of phosphate solubilizing bacteria from different regions of viskhapatnam and Araku Vally. Int. J. Adv. Biotechnol. Res. 4(4): 518-526.

El-Borollosy, M. and M.M. Oraby (2012). Induced systemic resistance against cucumber mosaic cucumovirus and promotion of cucumber growth by some plan growth promoting rhizobacteria. Faculty of Agriculture, Ain Shams University, Annals of Agriculture Science, 57(2): 91-97.

El-Hamdi, Kh.H.; R.E. Knany and Lamyaa, A. Abd ElRahman (2011). Evaluation of some multinutrient fertilizers for tomato and squash rotation and soil health under different irrigation systems. J. Soil Sci. and Agric. Eng. Mansoura Univ. 2(4): 393-406.

Hamissa, A.M.; F.M. Hammouda and R.E. Knany (2000). Response of nodulated faba bean crop to phosphate solubilizing bacteria under phosphorus fertilization and copper foliar spray application. J. Agric. Sci. Mansoura Univ., 25(5): 2995-3007.

Hayat, Q.; S. Hayat; M. Irfan and A Ahmad (2010). Effect of exogenous salicylic acid under changing environmental and Experimental Botany. 68: 1425 .
Huber, D.; V. Romheld and M. Weinmann (2012). Relationship between nutrition, plant disease and pests. In: Marschner's Mineral Nutrition of Higher Plants (Ed.): P. Marschner, $3^{\text {rd }}$ Edition. Academic Press, U.K. pp. 283-298.

Huber, D.M. and R.D. Graham (1999). The role of nutrition in crop resistance and tolerance to disease, in: Rengel Z. (Ed.), Mineral nutrition of crops fundamental mechanisms and implications. Food Product Press, New York, pp. 205-226.

Jackson, M.L. (1967). Soil chemical analysis. Prentice Hall, Inc. Englewood Cliffs. N.J.

James, D.; P.A. Trytten; D.J. Mackenzie; G.H.N. Towers and G.J. French (1997). Elimination of apple stem grooving virus by chemotherapy and development of an immune capture RT-PCR for rapid sensitive screening. Ann. App. Biol. 131: 459-470.

Javaheri, M.; K. Mashayekhi; A. Dadkhah and F.Z. Tavallaee (2012). Effect of salicylic acid on yield and quality characters of tomato fruit (Lycopersicon esculentum Mill.). Int. J. Agric. Crop Sci. 4(16): 1184-1187.

Karban, R. and Y. Chen (2007). Induced resistance in rice against insects. Bulletin of Entomological Res. 97: 327-335.

Kamil S.S.; S.A. Ahmed; I.A. Hassan and N.J. Qader (2015). Comparison of different levels of phosphate and biofertilizer of growth and yield of tomato (Lycopersicon esculentum Mill.) in green house conditions. Am. Euras. J. Agric. and Environ. Sci. 15(2): 210-215.

Keinath, P.A. and R. Loria (1996). Management of cotton scap of potato with plant nutrients, in: Engelhard W.A. (Ed.), Management of Disease with Macroand Microelements, APS Press, Minneapolis, USA, pp. 152-166.

Khan, A.A.; G. Jilani; M.S. Akhtar; S.M.S. Naqvi and M. Rasheed (2009). Phosphorus solubilizing bacteria occurrence, mechanisms and their role in crop production. J. Agric. Sci. 1: 48-58.

Khan, W.; B. Prithviraj and D.L. Smith (2003). Photosynthetic responses of corn and soybeen to foliar application of salicylates. J. Plant Physiol. 160: 485-492.

Khodary, S.F.A. (2004). Effect of salicylic acid on the growth, photosynthesis and carbohydrate metabolism in the salt stressed maize plants. Int. J. Agric. Bol., 6: 5-8.

Kloepper, J.W.; C.M. Ryu and S.A. Zhang (2004). Induced systemic resistance and promotion of plant growth by Bacillus spp. Phytopathology, 94: 1259-1266.

Kobeasy, M.I. and Salwa N.Z.A. El-Hamid (2005). Role of salicylic and parahydroxy benzoic acids as resistance inducer for barley strip mosaic virus infection in barley plants. J. Agric. Sci. Mansoura Univ., 30(8): 4929-4943.

Lancioni, P. (2008). Studies on biotic and abiotic elicitors inducing defense responses in tomato. Ph.D. Thesis, Phytopathology Dept., Fac. Agric., University of Bologna, Italy $125 \mathrm{pp}$. 
Leverson, A.L.; L.R. Lverson and S. Eshita (2001). The effects of surface applied jasmonic and salicylic acid on caterpillar growth and damage of tomato plants. Ohio J. of Sci. 101: 90-94.

Nanis, G.A.; R.E. Knany; Elham El-Refai and W.Y. Ali (2018). Potential use of beneficial salt tolerant bacteria for improving wheat productivity grown in salinized soil. J. Microb. Res. (June 2018) USA.

Pigna, M.; A.G. Caporale; V. Cozzolino; C. Fernandez Lopez; M.L. Mora; A. Sommella and A. Violante (2012). Influence of phosphorus on the arsenic uptake by tomato irrigated with arsenic solutions of four concentrations. J. Soil Sci. and Plant Nutrition 12(4): 775-784.

Qiang, Z. and O.H. Monica (2017). Effect of phosphorus rates on growth, yield and postharvest quality of tomato in a calcareous soil. Hort. Sci., 52: 1406-1412.

Radwan, D.E.M.; G. Lu; K.A. Fayez and S.Y. Mahmoud (2008). Protective action of salicylic acid against bean yellow mosaic virus infection in Vicia faba leaves. Journal of Plant Physiology, $165,845-857$.

Radwan, D.E.M.; K.A. Fayez; S.Y. Mahmud; A. Hamad; G. Lu (2007). Physiological and metabolic changes of Cucurbita pepo leaves in response to zucchini yellow mosaic virus (ZYMV) infection and salicylic acid treatment. Plant Physiology and Biochemistry, 45: 480-489.
Rashid, M.; M.Y. Shakir and M.T. Siddique (1995). Cotton leaf curl virus (CLCV) in relation to plant nutrition. In: Cotton Leaf Curl Virus. Ministry of Food, Agriculture and Livestock, Islamabad (National Workshop), Central Cotton Research Institute, Multan, pp. 94-96.

Shah, Y. and D.F. Klessig (1999). Salicylic acid, signal perception and transduction. In Hooy Kaas P.J.J.; Hall M.A.; Libbenga R.K. eds. Biochemistry and Molecular Biology of Plant Hormones. Elsevier Sci. Amsterdam, pp. 513-541.

Sharon, J.A.; L.T. Hathwaik; G.M. Glenn; S.H. Imam and C.C. Lee (2016). Isolation of efficient phosphate solubilizing bacteria capable of enhancing tomato plant growth. J. of Soil Sci. and Plant Nutrition 16(2): 525-536.

Snedecor, G.W. and W.G. Cochran (1967). Statistical Methods. $6^{\text {th }}$ ed. Iowa State Univ. Press, Ames, Iowa, USA.

Sreedevi Sarsan (2016). Effect of phosphate solubilizing bacteria (Bacillus PSB24) on growth of tomato plants. Int. J. Curr. Microbiol. App. Sci. 5(7): 311-320.

Tesfaye Balemi (2008). Response of tomato cultivars differing in growth habit to nitrogen and phosphorus fertilizers and spacing on vertisol in Ethiopia. Acta, Agric. Solvence 91(1): 103-119.

Turan, M.; N. Ataoglu and F. Sahin (2007). Effects of Bacillus Fs-3 on growth of tomato (Lycopersicon esculentum L.) plants and availability of phosphorus in soil. Plant Soil Environment, 53(2): 58-64.

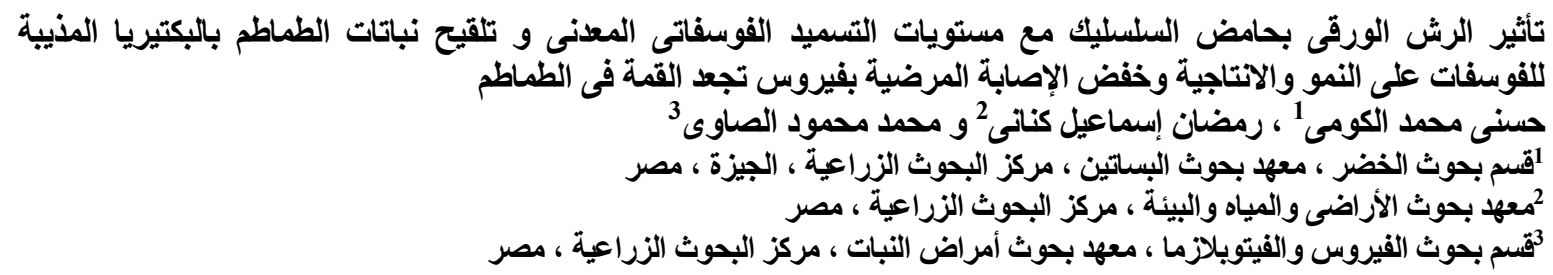

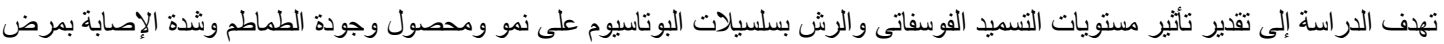

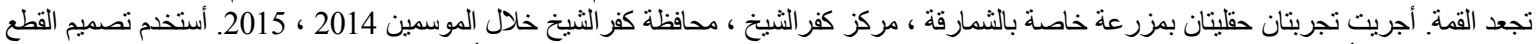

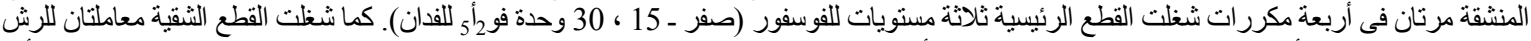

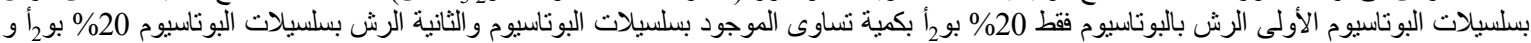

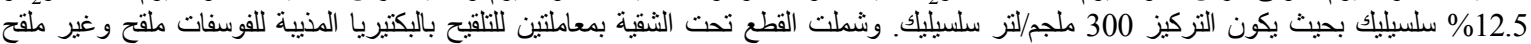

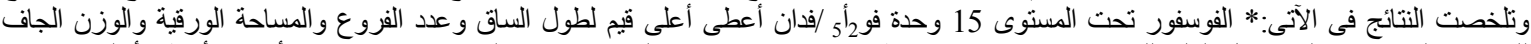

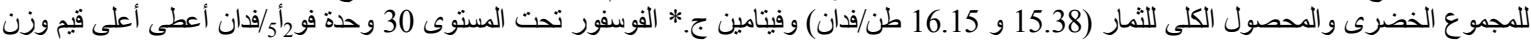

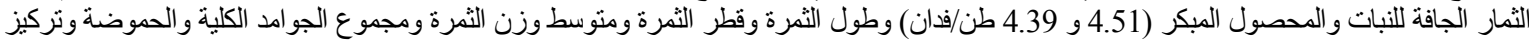

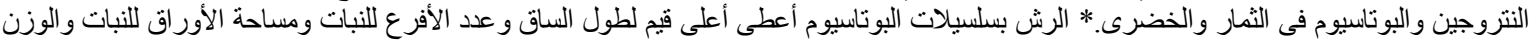

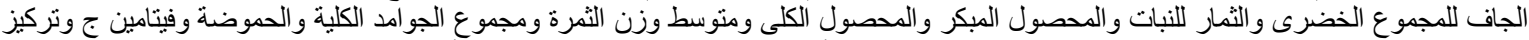

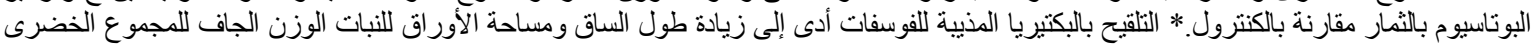

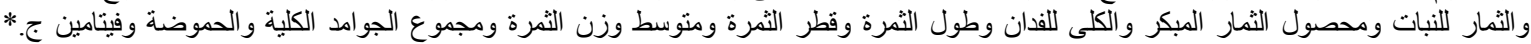

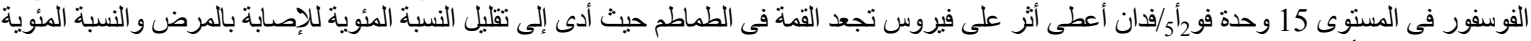

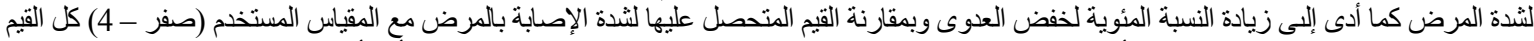

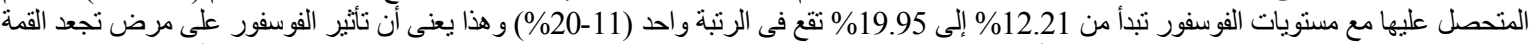

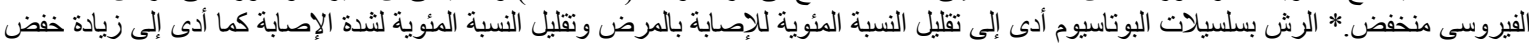

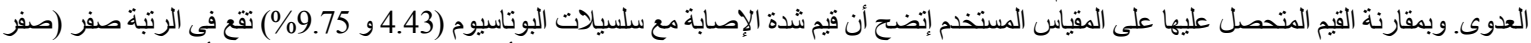

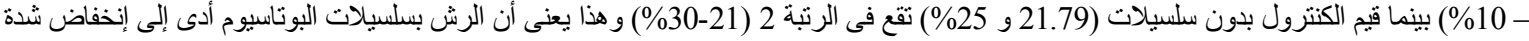

